U. S. COMMISSION OF FISH AND FISHERIES, GEORGE M. BOWERS, Commíssioner.

022

\title{
ARTIFICIAL PROPAGATION
}

OF

MARINE SPECIES

Extracted from the Revised Edition of the Fish Manual, Pages 195 to 238, Plates 64 to 63.

WASHINGTON:

GOVERNMENT PRINTING OFHICE.

1904 . 





\section{U. S. COMMISSION OF FISH AND FISHERIES,}

GEORGE M. BOWERS, Commissioner.

\section{2}

\section{ARTIFICIAL PROPAGATION}

$\mathrm{OF}$

\section{MARINE}

\section{SPECIES.}

Extracted from the Revised Edition of the Fish Manual. Pages 195 to 238, Plates 54 to 63.

\section{WASHINGTON :}

GOVERNMENT PRINTING OFFJCE.

1904 . 


$$
\text { 2: }
$$

$\begin{array}{rl}\text { D. OF } & \text { Dis } \\ \text { MAY } 7 \mathrm{y} & 1908\end{array}$

$\because \vdots \vdots$ 


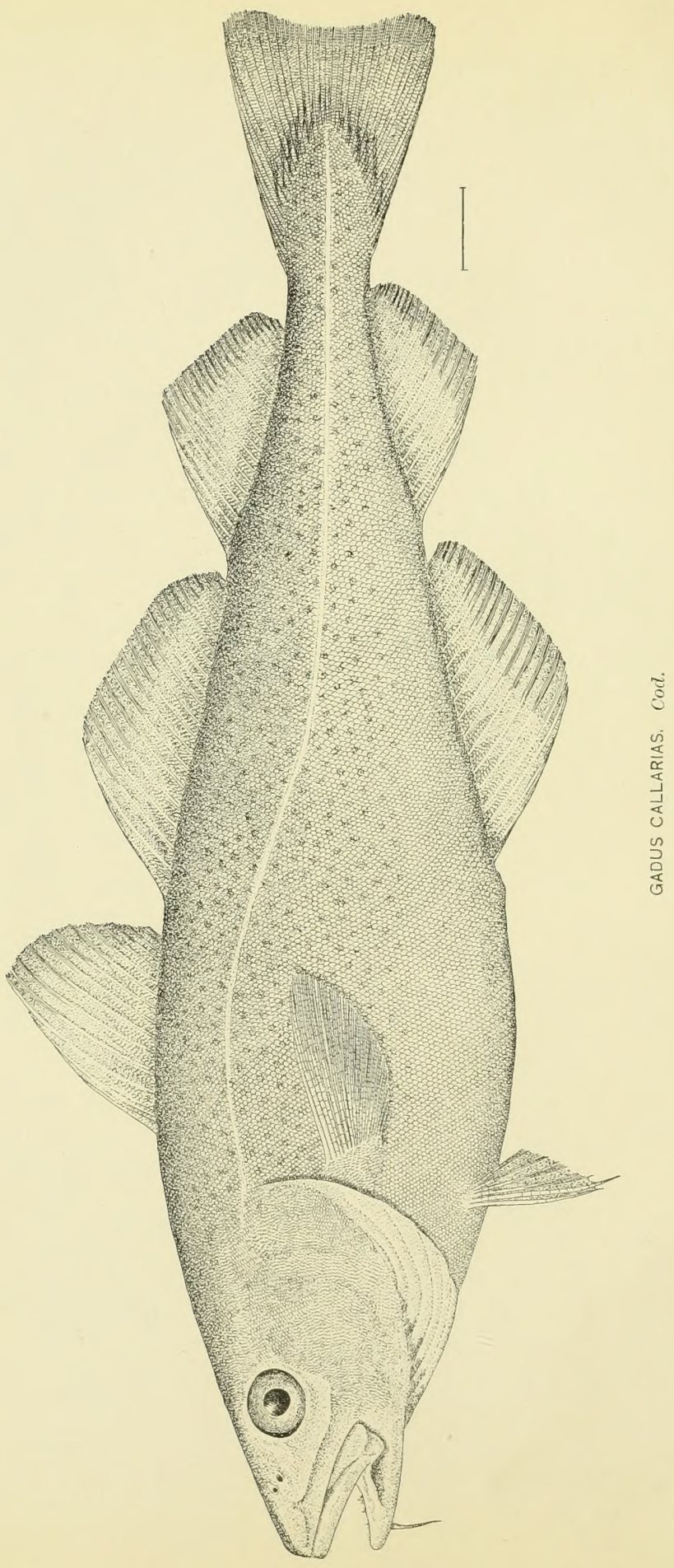




\section{THE COD.}

\section{DESCRIPTION OF THE FISH.}

The body of the cod is moderately long, compressed and tapering behind; the greatest depth is about one-fourth its length. The large head is narrowed anteriorly and is contained 3.3 to $4 \frac{1}{2}$ times in the borly length. The mouth is large; the lower jaw is included within the upper when the month is closed; the maxillary extends to about middle of eye. The diameter of the eye is abont half the length of the snout and one-fifth that of the head. There is a conspicuous barbel on the chin. The number of dorsal fins is 3 and of anal fins 2 ; the dorsal rays are usually about 14,21 , and 19 in the respective fins, and the anal rays are 20 and 18 .' The ventral fins are well developed, with about 7 rays. The cycloid scales, with which the borly is covererl, are rery small. 'The air-blatder is large and thick. The color varies greatly, repending on food, kind of bottom on which found, and other conditions. Fish talien offshore in deep water are usually olivaceous on the hack and whitish beneath; the so-called rock cod, found in shoaler water among rocks and kelp, vary in color from green to deep red. The back and sides are covered with small, round, reddish-brown spots. The lateral line is conspicuous, of a whitish color. The fins are dark.

From other species of the finmily, taken in the same waters, the cod is readily distinguished. From the haddock it differs in having a pale, instead of a black, lateral line; in its spots (absent in the laddock), and in its larger maxillary bone, which reaches past the eye, while in the haddock this bone does not extend to the eye. The features distinguishing the pollock from the cod are the smaller size, the projecting lower jaw, the uniform coloration above, the sharp snout, the smaller barbel, ete. The hakes have only 1 anal and 2 dorsal fins, a filamentous prolougation of the first dorsal ray, and a ventral fin consisting of two or three very long filamentous rays.

The status of the cod of the North Pacific Ocean is somerthat uncertain. It has generally been considered identical with the Atlantic species, but its smaller air-bladder and other features may entitle it to recognition as a distinct species.

\section{RANGE, MOVEMENTS, FOOD, ETC.}

Cod are widely distributed in the North Atlantic Ocean. To the north they range far beyond the Arctic Circle, and to the south as far as Cape Hatteras, althongh they are not common south of New Jersey. 
The cod of the North Pacific Ocean is found trom Bering Sea sonth to Oregon and Japan.

The movements of corl are not well understood. They go in schools, but in much less dense bodies than do mackerel, herring, and menhaden, and when moving from one ground to another they are in more compact schools than when on the feeding-gromds the movements on and off shore and from bank to bank are due to sereral causes, amoug which are the effects of water temperature, the presence or alosence of food, and the spawning instinct. In the winter months there is a well-marked movement of large bodies of codfish to the shores of the New England and Niddle States, and important fisheries are there carried on in regions from which cod are absent at other times. This movement seems to be chiefly for the purpose of finding shallow grounds for spawning. That the cod sometimes makes very long journeys is shown by their capture on the New England coast with peenliar hooks in their bodies which have been identified as similar to the hooks employed by the French cod tishermen on the Grand Banks.

Although sometimes found in shallow rater, cod are essentially decp). water fish, preferring water from 20 to 70 fathoms deep and being found even at a depth of 300 fathoms. Those caught for market are usually taken at depths of 20 to 40 fathoms.

The corl takes its food on the bottom, at the surface, or at intermediate points. It is an omnivorous aud extremely voracious feeder, consuming all marine animals of suitable size. Favorite articles are bivalve mollusks, crabs, lobsters, starfish, and fish. Among the fish consumed in large quantities are capelin, lant, herring, alewives, menharlen, mackerel, and haddock, althongh mauy others are also eaten. The abundance and movements of such fish have an important relation to the presence and abundance of cod in a given region.

\section{WEIGHT AND GROWTH OF COD.}

The largest cod recorded from New England waters weighed 211 pounds and was over 6 feet long; it was taken on a trawl off the northern Massarhusetts coast in May, 1895. The capture of a number weighing fiom 100 to 175 pounds could be cited, but those exceeding 100 pounds in weight are by no means common, and even 75 -pound cod are not numerous. The average weight of the large-size cod caught in the shore waters of New England is about 35 pounds; on Georges Bank, 25 pounds; on the Grand Banks and other eastern grounds, 20 pounds; the average weight of the small-size fish caught on all these grounds is about 12 pounds.

Observations in Massachusetts of the rate of growth of the cod show that those $1 \frac{1}{2}$ to 3 inches long are about 6 mouths old; those 9 to 13 inches long, and weighing $\tau$ or 8 ounces, are $1 \frac{1}{2}$ years old; those 18 inches long, and weighing 2 to 21 pounds, are 21 years old; and those about 22 inches long, aud having a werght of 4 to 5 pounds, are $3 \frac{1}{2}$ years old. 
SPAWNING.

The principal spawning time of the cod on the New England coast is winter, but the season begins as early as November and continues until April. Spawning fish are occasionally caught from October until May. The spawning period for an individual fish is greatly prolonged, aud probably covers six or eight reeks, only a small percentage of the eggs maturing at one time. The male and female col may attain sexual maturity when weighing only 3.1 or 4 pounds. The ages of normal fish having these reights are supposed to be three to four years.

When impelled by the spawning instinct, the cod seek the shoal waters of the coast or banks in schools consisting of both sexes. The female is less active than the male at this period, and probably rests quietly on the bottom while discharging the eggs. There is no evidence to show that the sexes are paired or in close proximity duriug the act of spawning. On the contrary, it seems likely that fertilization is generally accomplished by accidental contact of the sexual prorlucts as they are swept about by the elements, having risen to or near the surface as soon as extruded.

The cod is one of the most prolific fishes. The ovaries of a 21-pound fish have been computed to contain 2,700,000 eggs, and a 75-pound cod has beeu estimated to have $9,100,000 \mathrm{eggs}$, these figures being deduced by careful weigling or measuring of a known number of eggs. The egg is from $\frac{1}{19}$ to $-1 \frac{1}{7}$ inch in diameter, the smallest fishes having the smallest eggs; the average size may be taken as $i^{\frac{1}{8}}$ inch. The approximate number in a fluid quart is 337,000 .

The destruction of cod eggs in nature is necessarily large. The principal loss is probably through failure of impregnation, the eggs losmg then ability to become fertilized and the milt its vitality very soon after being thrown from the fish. Incalculable numbers are thrown on the shore hy the waves and there die. Cod eggs are also destroyed by numerous animals, including fish, birds, and invertebrates.

\section{COMMERCIAL IMPORTANCE AND FOOD VALUE.}

The cod is one of the most valuable of all food-fishes, and in the United States ranks as the most prominent commercial fish. In the matter of persous engaged, vessels employed, capital invested, and value of catch, the taking of corl in the United States is more extensive than any other fishery for fish proper.* 'The number of vessels which fish wholly for cod or take cod in noteworthy quantities, together with other "ground fish," is not less than 600 , of over 25,000 net tons burden, carrying about 7,000 men, and with a value of $\$ 3,000,000$, besides which there-are very large fisheries carried on from boats and small vessels of less than 5 tons burden. The approximate anuual value of the cod

\footnotetext{
* The oyster fishery is the most important brauch of the fishing industry of the United States.
} 
catch in 18 ! w was about $\$ 2,000,000$, a sum representing the first value of the dish. The weight of the fish as landed from the vessels (fresh, split, and salted) was about $96,000,000$ pounds.

The cod fishery is prosecuted in all the coastal States from Maine to New fersey, being most important in Massachusetts and Maine. Gloucester and Boston are the principal fishing centers. On the Pacific coast there is an important fishery in Alaska, carried on by San Francisco vessels.

Cod are taken with hand and trawl lines, baited with fish, squid, etc., and fished from small boats or the vessel's deck. The principal grounds in the Atlantic are the famons "banks"-Grand, Georges, Western, Quereau, etc.; on the Pacific coast the Shumagin Islands are the chief gromnds. Small quantities are taken in traps at places on the New England shore.

\section{ARTIFICIAL PIROPAGATION.}

The cod is propagated artificially on a more extensive scale than any other marine tish. Artificial hatehing was first undertaken at Gloucester, Massachusetts, in the winter of $1875-79$, and has since been regularly prosecuted on an increasingly large scale at both Gloucester and Woods Tole. Up to and including the season of 1896-97, the number of cod fry liberated by the Commission on the east coast was $449,764,000$. The output of fry in the last-named year was $98,000,000$. The unmistakable economic results which have attended these efforts warrant all the time and money devoted to them aud justify the greatest possible expansion of the work.

\section{COLLECTING EGGS ON THE FISHING-GROUNDS.}

The following methods are pursued in collecting cod eggs for the United States Fish Commission station at Gloucester.

As cod are abundant in Ipswich Bay during the winter, vessels from Gloncester, varying in size from 10 to 70 tons, engage in fishing there, starting from Kittery l'oint, Maine, or Portsmouth, New Hampshire, where they market their catch, secure bait, and obtain supplies. At the beginning of the cod season (which usually opens from the middle to the last of November) arrangements for the board of the men, dory and building hire, transportation of eggs, ete., are made with persons at Kittery Point and permission to place spawn-takers aboard the fishing vessels is obtained, with the understanding that they will be allowed to take eggs from the fish secured, that they be given the freedom of the vessel in order to properly care for the eggs, and that no eharges be made against the Commission except that 25 cents be paid for each meal furnished the spawn-takers. After these arrangements are made the men are directed to board such of the fleet as are at the time meeting with the best fishing, but as the fish are not of nniform abundance in the bay it is necessary to keep a vigilant wateh on each vessel's catch as it is landed, daily, to know where to place the sparn-takers to the best advantage. 


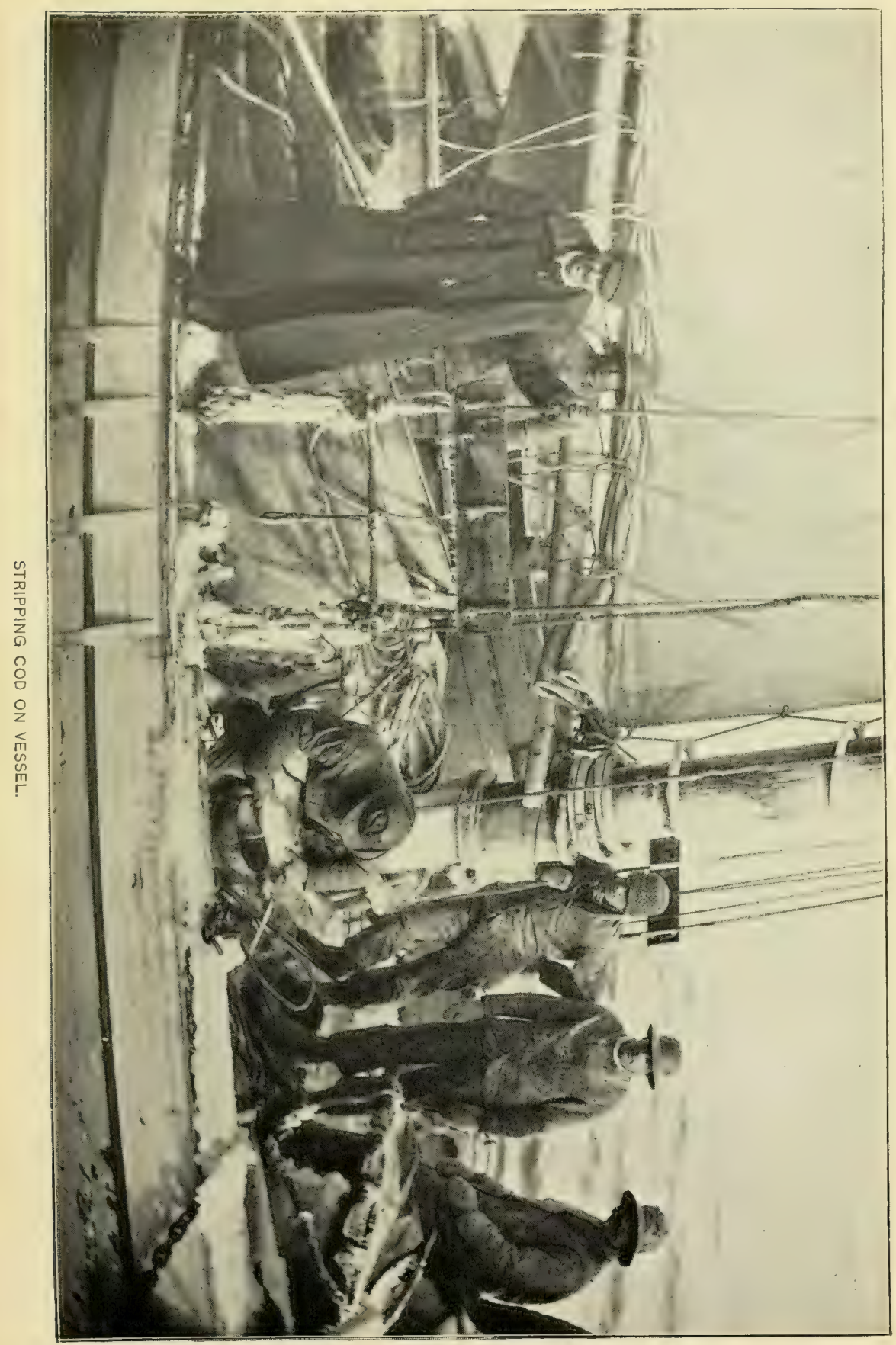



A sparn-taker's outfit cousists of a water bucket or pail, a dipper, a siphon, a thermometer, and a tin sparwn-kettle about 2 feet long, 1 foot wide, and 8 to ! inches deep; the liettle has a cover and handle.

When new spawn-takers are employed they are instructed in the rork and sent out in ressels with the experienced men to familiarize themselves with the methods. The spawn-takers ordinarily leave their boarding-places at 1 o'elock in the morning (thongh the time varies somewhat, according to the weather) and join the boats anchored in the harbor of Kittery or at Portsmouth. During moderate weather the men frequently go aboard before midnight, as the vessels must sail when the tide is favorable, to avoid gettiug becalmed or meeting a head tide, either of which might prevent them from reaching the tishing-grounds in good season.

After joining the vessels, the spawn-takers usially assist the fishermen in getting under way, managing the ship, ete., and on reaching the place where the mets or trawls are set-nsually 6 to 10 miles distautthe spawn-takers help the cress in hoisting out and dropping the dories on the gear as each buoy is reached, the men remaining on the vessel's deck with the captain while the fishermen are hauling or under-running their gear, and until they return to the vessel with the fish.

As soon as the dories begin to arrive with fish, the work of the spawntaker begins. As the fish are pitched aboard, the spawn-taker stands ready to examine each one and select those that may contain ripe eggs or milt. As the dories are usually picked up in the same order in which they are iropped, there is opportunity to strip the fish without much hurry, but sometimes several are picked up in a short space of time, and if a large quantity of fish is landed the catch remains on deck until the spawn-taker can overhaul it. In bad weather, however, when the fish would be in dauger of being washed array, they are put in bins on deck and can be pitched from one bin to another by the spawn. taker as the condition of each is determined. Usually one of the crew assists in this work and often renders valuable assistance. Great care is taken not to get any green or dead eggs with the good ones and to keep the eggs as free from foreign matter as possible; but in rough weather, when the vessel is pitching or rolling heavily, vigilance in these respects is necessarily somewhat relaxed.

The sparn-taker seizes the fish by the tail, places the head under the left arm, if it is not too large, leaving the right arm free for stripping the fish, which is done in the usual way. Only live fish or fish recently dead are used.

The eggs are first taken in a common pail, the inside of which has been moistened with water. Then a sufficient quantity of milt to fertilize the eggs is adderl and thoroughly mixed with them and allowed to remain from 10 to 20 minutes, or longer, after which water is added and the eggs are carefully cleaned by siphoning off the old water and putting in fresh water until all the slime and milt are drawn from the pail. The good eggs, which rise to the surface of the water, are 
then transferred to the spawn-kettle containing clean water and the poor or dead eggs are thrown away.

All the ewgs obtained on a given vessel are kept in the kettle until the receiring-house on shore is reached, the water on the eggs being changed at intervals during the passage in; and to keep the temperature miform, the eggs are shifted from one part of the vessel to another, according to conditions. Sometimes, when the sea is very choply or rough, the pail can not safely be used, as the eggs will spill ont, and they are then stripped directly in the spawn-kettle and cleaned as well as possible.

It was formerly the practice to take coll eggs in a small quantity of water, but duriug the season of $1.96-97$ it was determined to test the relative efficacy of the so-called wet and dry methods of fertilization. Some of the spawn-takers were instructed to employ the dry method aud others the wet method. The experiments show that when eggs were taken by the dry method a much larger percentage was fertilized than when taken in watel. Eggs from fish caught on trawl lines invariably yield a larger percentage of fry than those from fish eaught in nets, although tine eggs are frequently obtained from net fish. The explanation seems to be that fish caught in uets soou become entangled and are either drowned, or nearly so, shortly after being meshed; they struggle a great deal more thau fish on trawls aud the greater part of them are dearl when taken into the boats, many of them being sealed, which indicates severe exertion in trying to escape. Trawl fish, on the other hand, are almost always alive and active when taken from the water, and very ter fish without scales are found unless the gear has been ont a long time or has been set during a heary storm, when, of course, many of the fish will be dear.

Better results are obtained from eggs taken when the weather is fairly cold than when it is warm, as when the temperature is high it is difficult for spawn-takers to keep the water containing the eggs at a safe temperature, aud before the egg house on shore is reached there is almost always a heavy loss. When the meather is too cold for egers to be kept on the vessel's derk the spawn-takers put them below the deck, where the temperature will be suitable.

Many difficulties and much exposure are encountered by the men who collect cod eggs on the fishing vessels, and during severely cold and windy weather, when the deck is covered with ice and the fish. freeze stiff in the dories before they reach the vessel, it is practically impossible to get good eggs. I) uring boisterous weather, when the fleet succeeds in hauliug the gear only once or twice a week, the greater part of the catch is generally dead when taken. A spawn-taker often secures a good lot of eggs and can find no ripe milt fish, but in this event he will, if the weather permits, visit the nearest vessel in quest of milt. Sometimes there is a school of milt fish in the bay and very few female fish, and a vessel may eatch several thousand pounds of cod day after day without finding ripe spawn in any of them, while another 


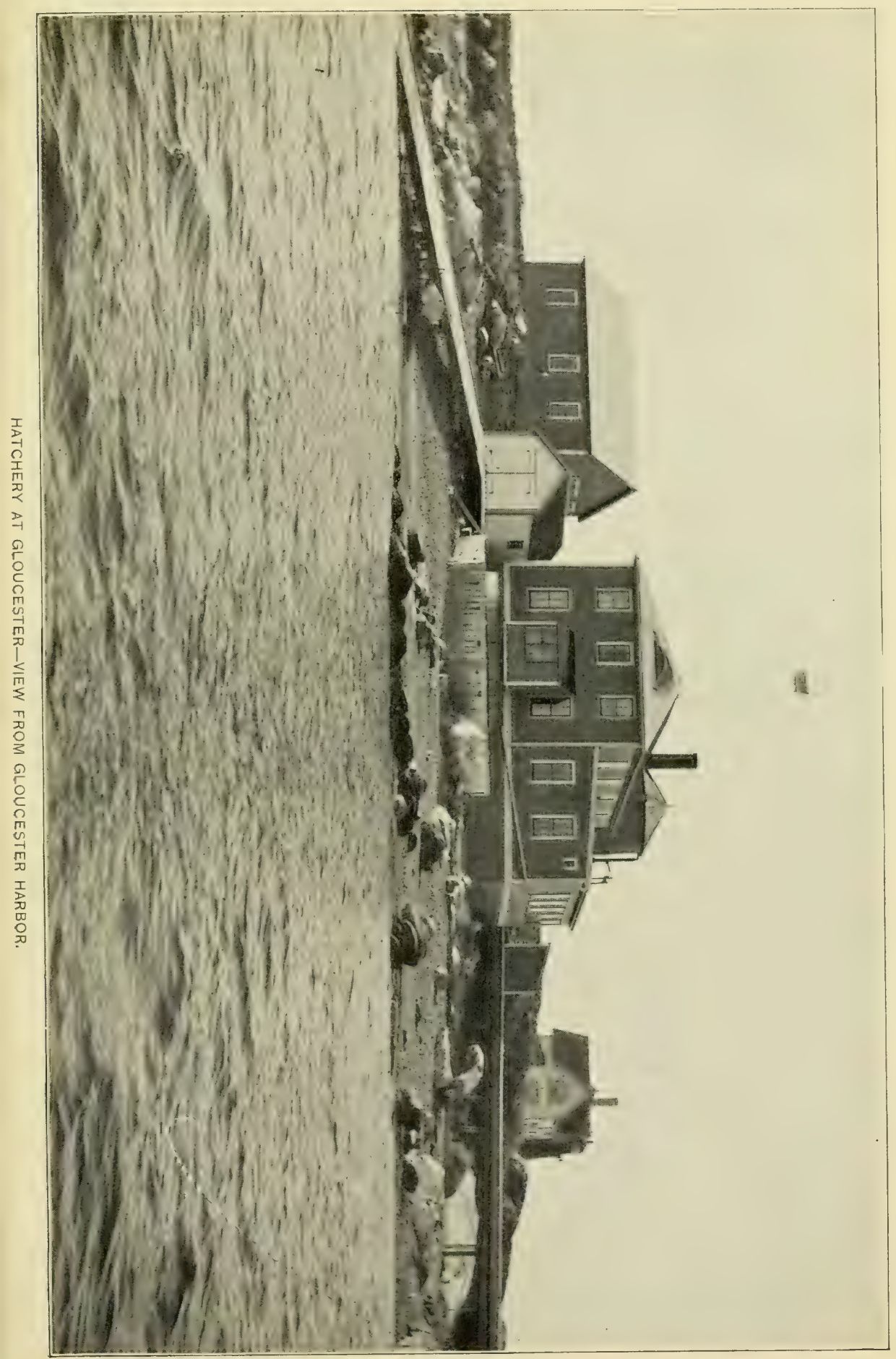



vessel, fishing only a short distance away and not catching many fish, will get a comparatively large number of spawners.

The spawn-takers are instructed not to take eggs from fish that have died on trawls or in nets, although fine lots of eggs are often taken from fish that die in the dories betore they reach the ressel, showing that the eggs do not die immediately after the fish expire. The vitality of the eggs after the death of the fish varies in different cases and denends on the conditions of the eggs and the fish at the time the fish are canglut, the state of the weather, etc. An experienced spawn-taker can almost always distinguish readily between good aur poor eggs, although it is not always possible to determine whether or not a given lot of eggs will live. As the weather and the nature of the school of fish in the bay regulate the collection of eggs, the results of a season's work can not be estimated in advance. It has been observed that roe fish are found in largest numbers previous to an easterly storm and when the wind is from the south or west. During heary westerly winds cod appear to approach quite close to the beach, and when the wind blows from the eastrard and the sea begins to rise, they leave for deeper water.

When fishermen are hauling their nets and trawls, they frequently notice spawn being emitted from fish when they are landed in the dories. Such fish are laid away on their backs in the stern of the boat and when the vessel is reached are carefully passed to the spawn-taker, many eggs that would otherwise be lost being thus saved.

When the price of fish is low at Portsmonth or the wind is nufavor. ahle for making that harbor, some of the fleet go to liockport to sell their fish, and should spawn-taker's be on such ressels they immediately take their eggs to Glonester when the vessels arrive in Tiockiport.

Usually the fishing ressels return to Kittery Point between 1 o'clock and $10 o^{\prime}$ 'dock p. m. Immediately on landing, the spawn-takers carry their collections to the egg.honse on shore, where the spawn is carefully examined, cleaned, packed, and shipped to (xloncester by first train. In shipping eggs large fruit jars are used. Abont 350,000 eggs are put in each jar, the jar is filled with water, the top is securely fastened, and the jar is placed horizontally in a large iron kettle made especially for the purpose and holding five jars. The jars are wrapped in burlap before they are put in the kettles, to prevent them from breaking, and, Then necessary, snow or ice is put in each end of the kettles to keep the temperature uniform during transit, but it is not allowed to come in direct contact with the jars.

A messenger usually accompanies the eggs and gives them constant attention until they are delirered at the station. The snow or ice is removed from the kettles, if the temperature falls too low, and replaced, if necessary, the messenger making frequent use of a thermometer.

In preparing eggs for shipment without messenger, they are first cleaned carefully by drawing off all dead eggs or dirt, then put in large fruit jars in the same manner as when they are shipped to (iloucester, and the jars are packed horizontally in large wooden cases holding nine 
jars each. liockiveed or moss, together with ice or snow, is used in packing them. the former being placen around the jars and the latter put in the buttom, sides, and top of the case to lieep the egrgs cool. Successful shipments are ofteu made by express.

sonme diftieulty has been experienced in keeping large lots of eggs over night at Kittery Point, as the facilities are insufficient for changing water or for spreading the eggs out to overcome the injurious effects of prolonged crowding; but when it is necessary to so retain them, they are put in IrCDonald jars in which the water is changed as often as the supply will permit. As the water in the harbor is partly fresh aud unfit for this purpose, it is necessary for spawn-takers to bring in a supply from the open bay in large transportation cans.

\section{CAPTURING AND PENNING BROOD COD.}

Practically all of the cod fry hatched at Woods Hole prior to 1896 represented eggs taken from penned fish. Some of the corl collected for breeders are eaught by the crew of the Fish Commission schooner Grampus and some are purchased from commercial fishermen. Two or more smacks usually engage in fishing for the station during the collecting season, which is from about October 1 to November 30. The grounds resorted to are east of Nintucket and around Block Island. The fish are taken with hand lines fished from the deck while the vessel is drilting, in water from 10 to 40 fathoms deep. Those talien in the shoaler water are preferable to those coming from deep water, as the change to the shallow cars in which they are held at the station is less pronomeed. Great care is exercised in eatching the fish, for when hastily hauled up from deep water they are very liable to be "pokeblown," that is, they have their stomachs turned inside ont through the month. When drawn in with molerate speed, they become adapted to the gradually diminishing pressure and do not suffer injury. It is also important in unhooking the fish not to injure its month any more than is absolutely necessary, as the wound caused by the hook frequently spreads and forms a large sore and eventually kills the fish. All the vessels which collect cod for the station are provided with wells in which the fish are placed and held while in transit.

When a ressel arrives at the station with eorl, the fish are immediately transferred with dip nets from the well to live-car's 16 feet long, if feet witle, and 5 feet deep, which are constructed of wood and divided into two compartments by a crosswise partition. As the fish obtained from smacks are paid for by the pound, it is customary to weigh abont 10 per cent of each loak and estimate the total weight by the average of those weighed. While being weighed, the cod are also counted, abont 500 being put in each car. The cars are moored in the middle of a pool or basin protected on all sides by a wharf, which breaks the force of the sea in stormy weather and affords a sheltered place for handling the fish and taking the eggs.

Cod take little or no food when spawning. The impounded brood fish are often tempted with fresh fish and with fresh and salted clams, 
but they can rarely be induced to eat. I certain percentage of the penned fish die and are remored at once from the car's. The derelopment of the sexual organs is noted when the dead fish are taken out. Fish about reatly to spawn are placed in a separate car and carefully watched. They are examined tro or three times at week and any ripe eggs are taken.

In taking and fertilizing the eggs of brood cod the same general methods are followed as are adopted on the fishing ressels in Ipswich Bay. The spawn-taker grasps the ripe fish near the tail with his left haud and holds the fish's head either between his body and left arm or between his thighs, using his right hand to strip the tish. The eggs are nsually taken in a bucket. Both the dry and wet methods of fertilization are used at Woods IIole. Usualiy about $\$ 0$ per cent of the eggs taken are fertilized. Tnlilie many other fishes artiticially propagaterl, the cod does not yiehl all of its eggs at one time. After expressing all the egg' possible from a given lish, it is returned to the live-car, and in a few days will have matured more eggs, which are then taken. When the ovaries have discharged all their eggs, the fish is released.

In recent years from 1,600 to $9,000 \mathrm{cod}$ have been penned annually in the protected basin at Woods Hole. Only from one-ninth to onethird of these, according to the season, yield good eggs.

\section{CHARACTERISTICS OF COD EGGS.}

Cod eggs are nearly transparent, and float at the surface of the water when first taken. They vary in color from a pale green to a deep red, those having the green color being the best. Good results are seldom obtained from the red eggs, and those of a deep red color almost iuvariably die in three or four days after being received. Inless the density of the water is low, the eggs normally float during the entire hatching period. However, it frequently happens that, owing probably to the accumulation of sediment, the eggs gradually sink during the last third of the incubation period, and finally mass together on the botton of the hatching-hox; here they would quickly smother but for the current.

Floating eggs are not necessarily good ones, for unfertilized and injured eggs usually float $1 \mathrm{~s}$ to 36 hours before going to the bottom. Lnfertilized eggs may be readily detected, as they have no dise which marks fertilization and have a milky appearance. The dread eggs quickly sink, and are easily distinguished from the sound eggs by a white spot in the center.

Eggs received at the hatchery are transferred from the vessels in which they came to Chester jars partly filled with water, and in 10 or 15 minntes they rise to the surface in a dense mass. The eggs are put in each jar to the depth of an iuch, a quantity representing approx-. imately 379,000 eggs. If the hatehery is full, about a fifth more eggs may be put in a box, the maximum number that may be safely carried being 450,000 . The first measurements are carefully made, as they form the basis for subserquent estimates. As soon as the eggs are measured they are transferred to the hatching-boxes with dippers. 
TIE APPARATUS USED IN HATCHING COD.

The apparatus and methods employed in cod-culture are the ontgrowth of Jong experience and study and have as their special features the closest possible simulation of nitural conditious. The apparatus now in general use is the so-called MeDonald or automatir tirlal box. The boxes are constructed in series of 12 or less, the number depend-
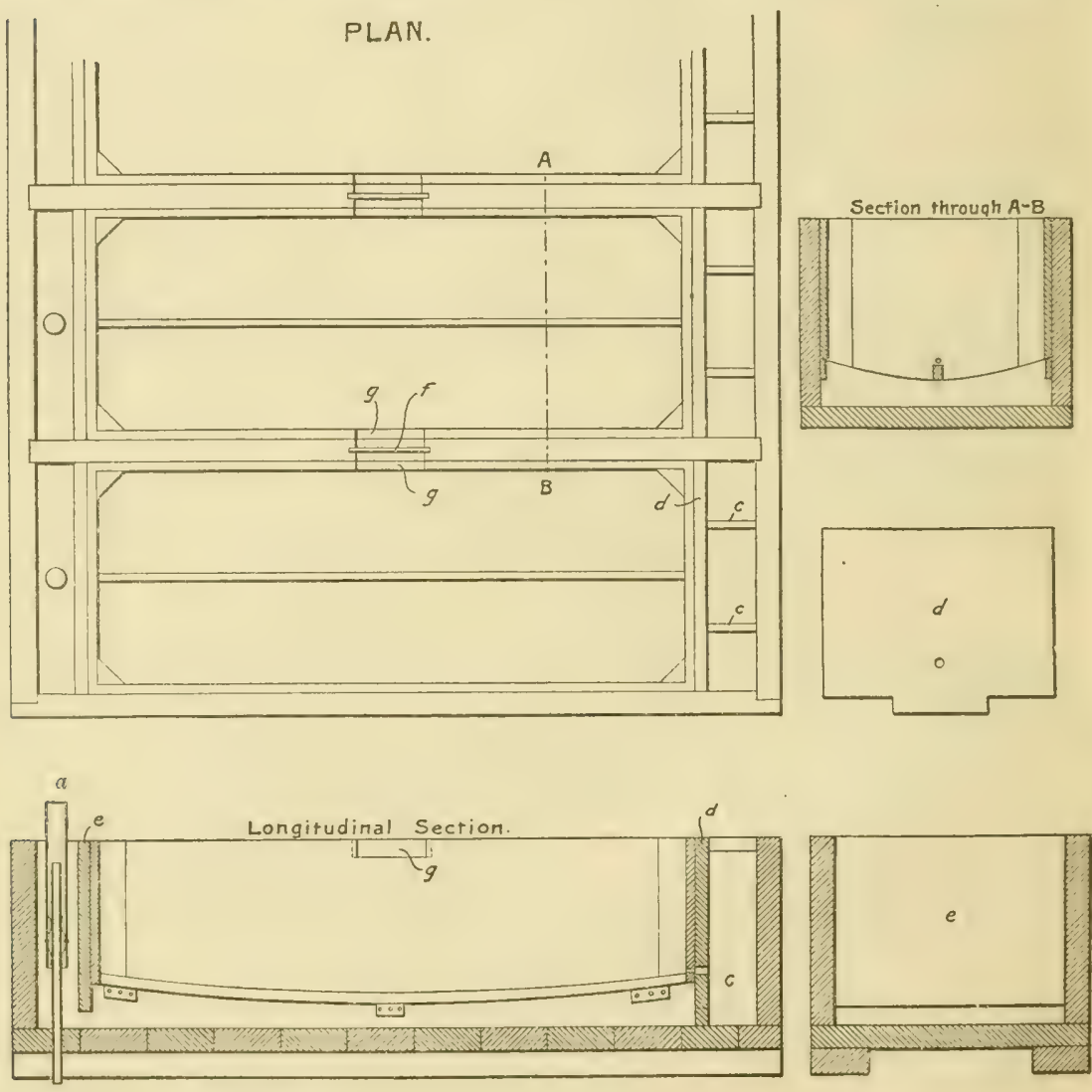

$$
12 \text { INCHES }
$$
1

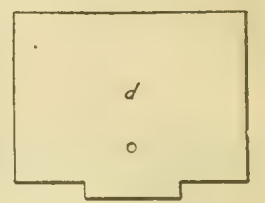

Diagram of Tilal Cod Hatching-Box.

A-T Points where cross-section is taken. a, siphon.

c, partitions forming upper pockets.

d, partition forming space at upper end of compartment. $e$, partition forming space at lower eud of compartment.

$f$, glass gate.

$g$, slot between adjoining compartments.

ing on the size of the hatching-room, the arrangement of the hatchingtables, or other conditions. The Gloncester hatchery has 8 tables of 9 boxes each, and Woods Hole 14 tables of 12 each. At Gloucester 25,000,000 eggs can be hatched at one time, and at Woods Hole $65,000,000$. For a wooden framework to accommodate 9 boxes such as are used at Glowcester the outside dimensions are: Length, 10 


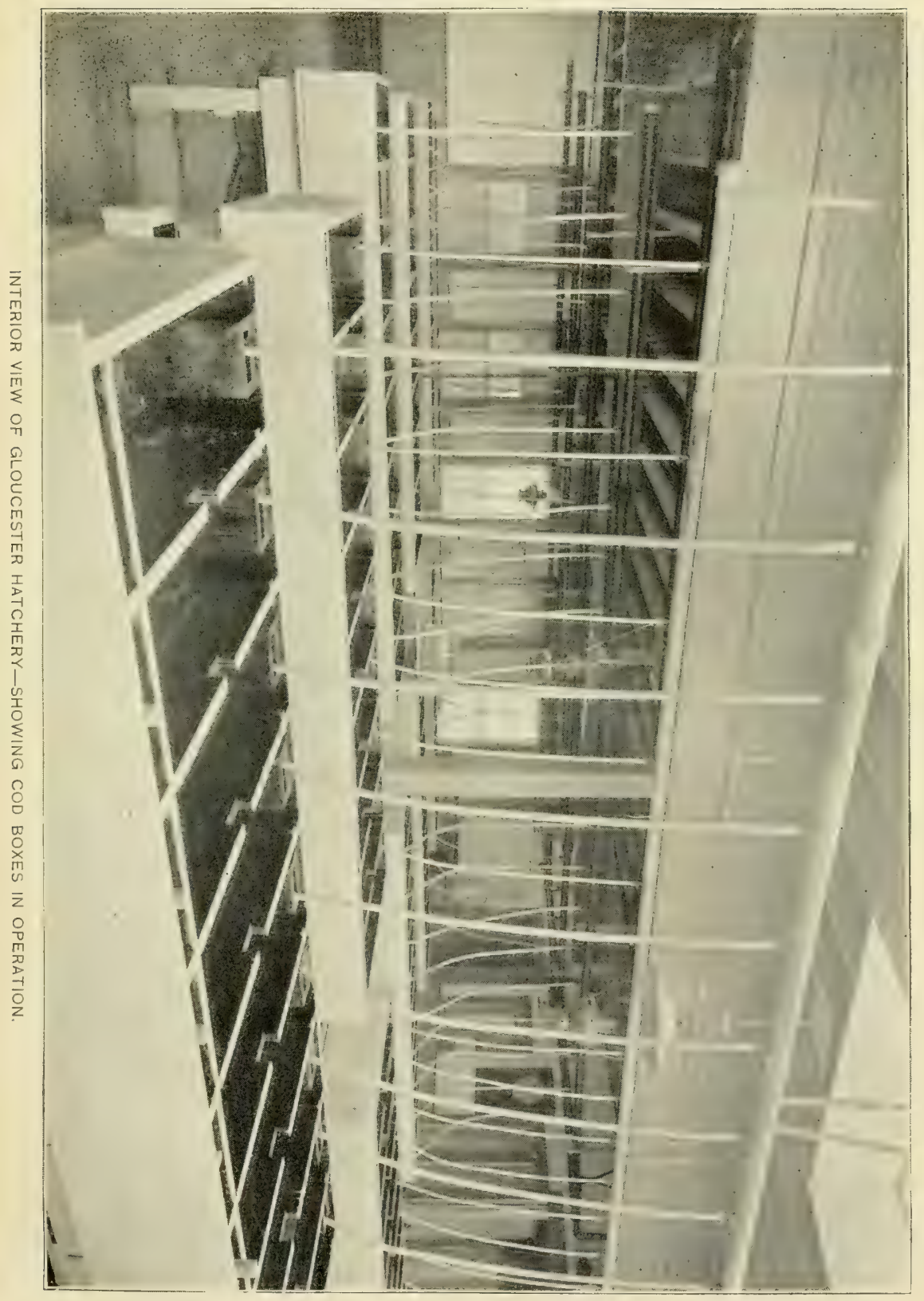



feet; width, 3 feet $S$ inches; depth, 11 inches. The table or trough is constructed of 2-inch lumber and raised to a convenient height by short, stout legs. The table is divided into 9 water-tight compartments by means of crosswise partitions of $1 \frac{1}{2}$-inch plank.

At Woods Hole the dimensions of the troughs containing 12 boxes are as follows: Length over all, 13 feet; width, 2 feet 7 inches; depth, 12 inches. The plank is 12 inches thick. The bottom of the trough is $2 \frac{1}{2}$ feet above the floor. The compartments are separated by 11 -inch partitious and are 22 inches long, 12 inches wide, and $10 \frac{3}{1}$ or 11 inches deep.

Two inches from each end of each compartment there is a 1-inch wood partition. The partition $d$ at the supply or upper end of the compartment extends with its middle portion to the bottom of the trongh, while the two sides extend only to within $1 \frac{1}{2}$ inches of the bottom. The partition $e$, at the discharge or lower end of the compartment, extends its full length to within $1 \frac{1}{2}$ inches of the bottom of the trough. Between the two partitions $d$ and $e$ in each compartment there is snugly fitted a movable box in which the eggs are placed. This box, which is constructed of $\frac{1}{2}$ inch plank, is 9 to $9 \frac{1}{2}$ inches deep in the center, but only $S$ inches deep at the corners, the bottom sloping npward toward the sides and ends of the box and being covered with linen scrim. A wooden strip at the bottom, $\frac{1}{2}$ inch thick and conforming to the shape of the bottom of the box, extends the length of the box. The box rests on cleats in the corners of the compartments which keep the center of the box $1 \frac{1}{2}$ inches above the bottom of the trough.

The space at the supply end of each compartment is divided into three pockets by 1 -inch wood partitions. The middle pocket connects with the main compartment by means of a small hole $\left(\frac{3}{16}\right.$ to $\frac{8}{16}$ inch) through the center of the partition and end of the box immediately above the lengthwise strip, and the two lateral pockets connect by a space at the bottom with the main compartment.

At Woods Hole the water used in hatching is pumped from the harbor to two tanks of about 18,000 gallons joint eapacity. The water is led to the hatching-room through a 4 -inch wooden pipe and is supplied to the hatching apparatus through a 2 -inch hard-rubber pipe which branches from the main pipe and runs directly over each row of tables. At Gloucester the main supply-pipe is of hard rubber, 3 inches in diameter; this leads from a tank of 15,000 gallons capacity, the bottom of which is about 6 feet above the level of the troughs. A small soft-rubber tube, provided with a rubber pet-cock, carries the water to the middle pocket at the back of each box. As the pocket is always full of water when the boxes are in operation, a considerable amount of water goes through the small hole with much force, creating a strong current in the box and keeping the eggs in constant rotary motion. This current is one of the principal features of the apparatus.

Much more water enters the middle pocket than can pass through the small hole into the box, aud the surplis flows over the sides and 
enters the main compartment from below, coming up through the serim. covered bottom into the movable box.

The partition forming the pocket at the lower or front end of the box only extends to within 1! inches of the bottom, leaving a space through which the water ruus from the compartment. In the bottom of the pocket there is an opening in which the vertical waste-pipe fits. This pipe is brass, $\frac{1}{2}$ inch in diameter and 10 or 11 inches long: the top of the pipe is 7 inches above the bottom of the table. The waste-pipes from the differeut boxes discharge into a trough which carries the water from the building.

A particularly important part, and the one which gives the name "tidal box" to the apparatus, is used in conjunction with the wastepipe. This is a brass siphon-cap, which fits over the mpper end of the waste pipe. The cap is a tube, closerl at the top, 9 inches long and 1 . inches in diameter. It is kept at any desired height on the waste-pipe by wire springs in the cap or by other means.

By virtue of the siphon attachment the water in each box rises to the lieight of the top of the waste-pipe and begins to run over. This partly exhansts the air in the cap, more water rushes in, and the pipe becomes filled with water; then the siphon begins to act and takes ofi' the water to a level of the bottom of the siphon-cap. Usually the cap is pushed about half down the waste-tube, although the height of the water in the box after the discharge of the siphon is regulated by the manner in which the eggs are working. About 7 minutes are required for the water to be drawn down and the box to again fill, and approximately two-fifths of the water is taken off at each discharge. By this arrangement the water in the boxes is constantly rising and falling: automatically; the movements of the waves are thus simulated, the eggs are kept in coustant circulation, and fresh water is continually entering the boxes.

The Chester box was generally used in cod-culture up to a comparatively recent date, and is still occasionally employed in marine fish-cultural operations. The general object of its construction is the production of an antomatic rise and fall of water, as in the MrcDonald box, although it differs from the latter in some essential particulars. It consists of a box of variabde dimensions in which jars are placed for the reception of the eggs. A convenient size of box is $7 !$ feet long, 2 feet wide, and 21 feet deep). From 4 to 8 large glass jars are arranged on wooden supports 7 or 8 inches above the bottom of the trough. Smaller boxes, to accommodate only 2 or 4 jar's, are also used. The jar's are abont 9 inches in diameter and are of two heights -9 inches and 17 or 18 inches; they have straight sides and a flat bottom with a central half-inch hole.

The jar is placed in the box in an inverted position, with its bottom above the level of the top of the trough. The sea water supplying the trough enters the compartment at one end of the trough and escapes 


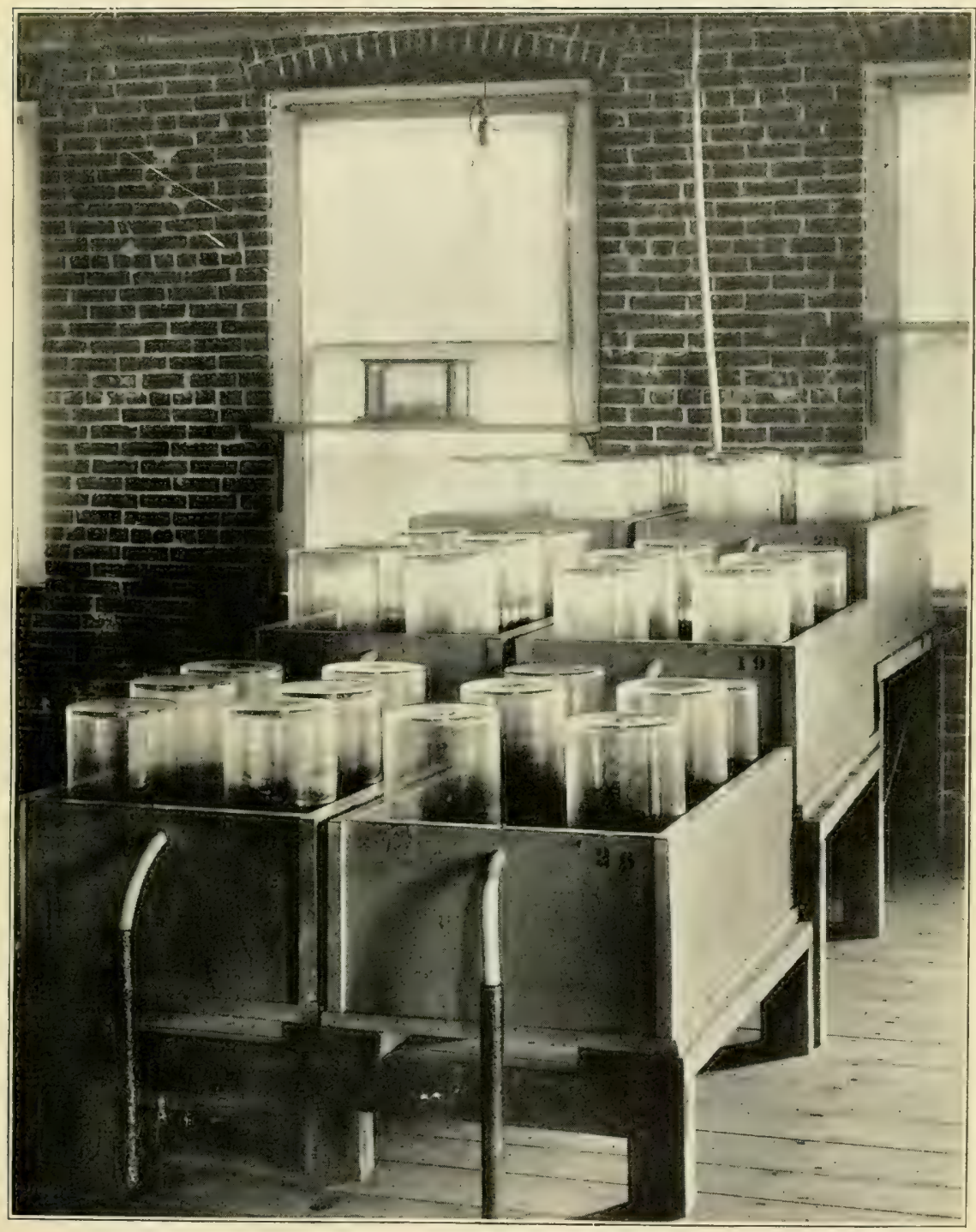

CHESTER BOXES. 

by means of a siphon in the other compartment, rumning through a hole several inches below the top of the trough. The trough fills with water up to a level with the hole, when the siphon begins to act and takes off the water more rapidly than it enters, to a level with the inner end of the siphon, the fall being 4 to 5 inches. Air then enters the siphon, and it ceases to act until the water has again risen to the height of the discharge hole. The water thus rises aud falls in the jars automatically, the interval between the successive discharges being regulated by the length of the inner arm of the siphon, the size of the tube, and amount of water supplied.

After the eggs are introduced into the jars a piece of cheese-cloth or linen scrim is placed over the top, and fastened by means of rubber bands. The jar is then inverted and placed on the wooden supports provided for the purpose, and the plug in the bottom removerl to allow the escape of the air and the rise and fall of water. The number of eggs per jar is about 190,000 or 200,000 .

\section{DEVELOPIENT OF THE EGG.}

The development of the cod egg is greatly influenced by the water temperature, which fluctuates from day to day and makes it difficult to state exactly when the eggs will hatch. With a high temperature the arlvancement of the egg through the different stages proceeds rapidly and can readily be appreciated with the nnaided eye, while with a low temperature the development is slow and may be greatly prolonged by very cold water. With a mean temperature of $47^{\circ}$ cod eggs begin to hatch in 11 days, althongh 2 or 3 additional days are usually necessary for all the eggs of a given lot to hatch. At $13^{\circ}$ the time is 14 or 15 days, and at $38^{\circ}$ it is 20 to 23 days. The best results are obtained when the temperature ranges from $41^{\circ}$ to $47^{\circ}$. The hatching proceeds satisfactorily with the water at $38^{\circ}$, but with a lower temperature the incubation period is so long that the fry are very weak. On the natural spawning-grounds the water seldom gets below $38^{\circ}$, while at the stations after January 1 the water used for hatching rarely gets as warm as $37^{\circ}$, and often is as low as $31^{\circ}$; from the middle of January to the latter part of February it remains at about $32^{\circ}$. Since it is impossible to do even fair work when the water gets below $35 \circ$, it has been the practice to warm the water by passing it through a coil of pipe contained in a tank of warm water or by introducing steam directly into the water pipe whenever the hatchery water gets below $37^{\circ}$.

The water being at $47^{\circ}$, during the first 4 days the egg passes through the different stages of segmentation; at the end of that time the germinal area begins to assume the general form of a fish; and by the ninth day the fish is quite well formed, and may be readily seen with the naked eye. By the tenth day the embryo shows sigus of life, and under the microscope the heart may be seen to beat. 
Following is a table slowing the approximate time required for cod eggs to hatch, with the water at the stated mean temperatures:

\begin{tabular}{|c|c|c|c|c|c|}
\hline $\begin{array}{c}\text { Mean water tem- } \\
\text { perature. }\end{array}$ & $\begin{array}{l}\text { No. of } \\
\text { days. }\end{array}$ & $\begin{array}{c}\text { Mean water tem- } \\
\text { perature. }\end{array}$ & $\begin{array}{l}\text { No. of } \\
\text { days. }\end{array}$ & $\begin{array}{c}\text { Mean water tem- } \\
\text { perature. }\end{array}$ & $\begin{array}{l}\text { No. of } \\
\text { days. }\end{array}$ \\
\hline 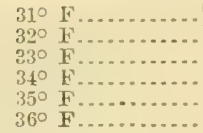 & $\begin{array}{l}50 \\
40 \\
35 \\
31 \\
28 \\
25\end{array}$ & 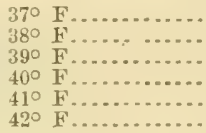 & $\begin{array}{l}23 \\
21 \\
19 \\
17 \\
16 \\
15\end{array}$ & 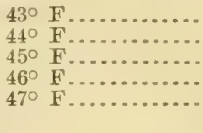 & $\begin{array}{r}14 \\
13 \\
12 \\
11 \\
10 \text { or } 11\end{array}$ \\
\hline
\end{tabular}

Moderately clear water is essential to the healthy development of the fry. If much sediment is present it collects on the eggs and acts very injuriously, often killing them. Sometimes eggs become so coated with sediment that the fry appear to be unable to burst the shell; some lots of eggs thus affected have been known to retain fry fully two weeks beyoud the normal period of incubation.

With eggs carefully taken and fertilizerl, and clear water of a temperature from $41^{\circ}$ to $47^{\circ} \mathrm{F}$, it is possible to hateh from 70 to 85 per cent of the eggs, but when the temperature gets below 380 the percentage of fry hatched is only from 25 to 50 , and the average for the season is thus greatly reduced. The number of fry hatched is determined by deducting the losses shown on the hatching-cards from the number of eggs originally in the box. One liquid ounce is estimated to contain 10,524 eggs.

\section{CLEANING THE EGGS.}

Owing to the accumulation of sediment and other foreign matters in the hatching-boxes, it is necessary to clean the eggs daily, rumning the sound eggs from one box to another throngh a slot, the dead eggs being left behind. The slots in the partitions dividing the hatching compartments correspoud with similar slots in the boxes; they are 3 to $3 \frac{1}{2}$ inches long and $1 \frac{1}{2}$ inches deep, and are placed 3 inches from the front of the compartments. To begin the cleaning of a given row of boxes, a glass slip is fitted into the slot between the second and third boxes, the first box being left empty for the purpose of receiving the cleaned eggs from the second box. A rooden plug is then put in the current hole at the back of the second box, and the siphon cap is removed from the waste-pipe; this allows the box to fill with water, and the eggs, nudisturbed by the current, rise to the surface. The water is allowed to enter the first box and to gradually fill it to the level of the waste-pipe, and is then turned off. A plug is next put in the waste-pipe of the box containing the eggs; the water rises till it reaches the slot, and then runs over in to the first box, carrying the good eggs with it, while the dead eggs remain in the box. The regular water circulation is then established in the first box.

The inner box from which the good eggs have been removed is taken out and the remaining eggs are washed into one end and poured into 
a glass graduate. The dead eggs quickly sink and the quantity, in onnces, is noted on a card attached to each box. If there are any good eggs in the glass they are sared; the spoiled eggs are thrown into the waste-trongh. Both the inner box and the trough in which it rests are thoroughly washed and sponged after each change.

When the inner box is replaced it is made ready for the eggs to be transferred from the third box, and the same method is pursued until all the boxes have been cleaned. Eggs recently taken, being on the surface, run over very quickly, 5 or 10 minutes usually sufficing for the transfer of a box of $400,000 \mathrm{eggs}$; but when eggs become heavier, as a result of development, the cleaning takes much longer, as it is then necessary to run them into the lotrer part of the box (as in removing (lead eggs) and to dip them out, care being taken to keep the lower end of the box in the water while manipulating them. As the loss of eggrs has ceased by the time they reach this stage, everything in the box may be dipped over, and with eare no damage is dlone the eggs.

\section{THE FRY.}

When the fry first hatch they are much curved in shape and show but little vigor. If the water is comparatively warm they rapidly straighten ont and become stronger. At this stage they float at the surface, except when forced about by the current. As they get older they frerguent the upper water less and if kept in the boses till the mouth begins to functionate most of them remain on or near the bottom.

As soon as the first fry in a given box make their appearance the eggs are all rumever for the last time. As the fry are comparatively delicate they are handled as little as possible and with great care.

The fry are planted as soon as practicable. If all the eggs of a given lot have not hatehed it is better to plant them with the fry rather than hold the latter until incubation is complete, for the boxes soon become foul from the accumulation of eggshells and the eggs will hatod in a very short time, especially as the water on the spawningegrounds is usually 3 or 4 degrees warmer than the water in the hatchery.

When the fry are to be remover from the boxes, preparatory to planting, a plug is put in the current hole at the back of the box, and in a short time most of them will come to the surface. They are then dipped out and put in transportation cans. About 200,000 fry may be safely carried in a 10-gallon can. Deposits are usually uade on the natural spawning-grounds. 




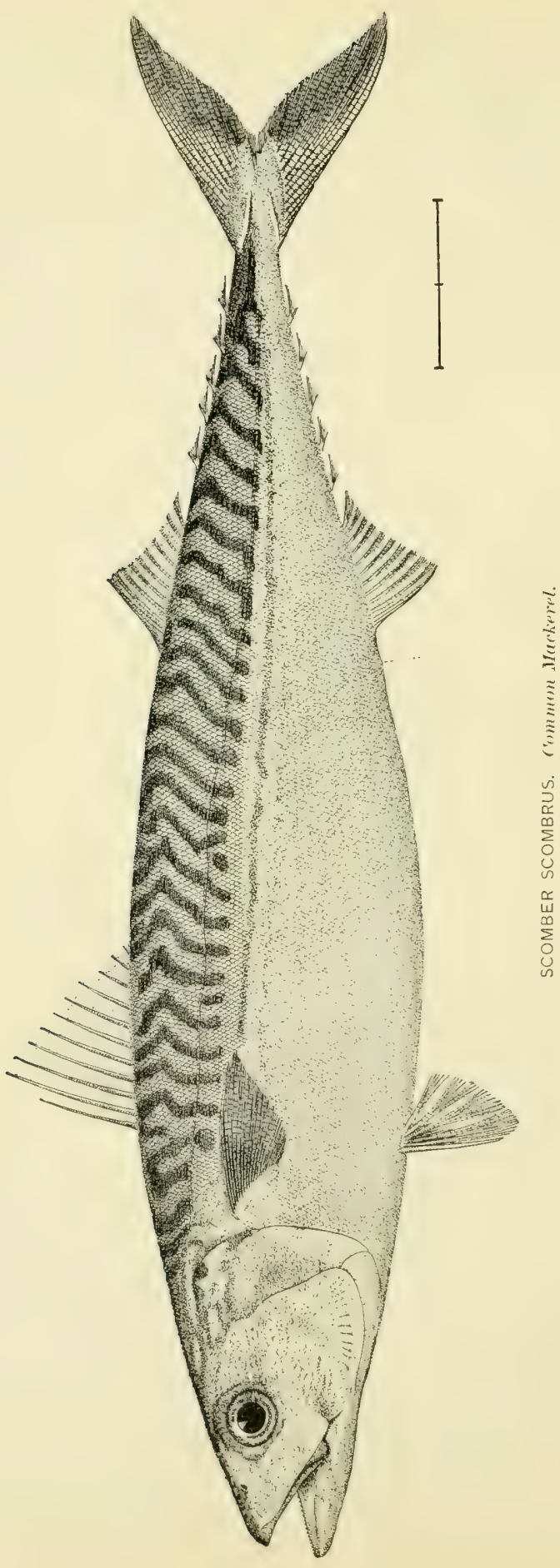




\section{THE MACKEREL.}

DESCRIPTION, SIZE, ETC.

The genus Scomber, of which the mackerel (Scombor scombrus) is the leading representative, is distinguished from related genera of scombroirl tishes of the Atlantic coast ( 1 uxis, the frigate mackerels; Gymnosarda, the little tumnies; Thummus, the great tumnies; Sarla, the bonitos, and somberomorus, the Spanish markerels and kingfish) by the small size of the species, by the absence of a median keel on each side of the caudal peduncle, by a short spinous dorsal fin having 9 to 12 spines, by the pattern of coloration, and by a number of other characters.

The body of the mackerel is fusiform and but little compressed laterally. The standard length is : $3 \frac{1}{2}$ times the depth. The caudal peduncle is slender, with a small keel on either side. One-third of the total length without tail consists of the hear. The eye is rather small, its diameter being only one-fith the length of the hear. The mouth is large and armed with a row of small slender teeth in each jaw. There are tro dorsal fins, the anterior containing 11 spines and the posterior 12 rays, following which are 5 finlets; the formula of the anal fin is 1 spine, 11 rays, and $\dot{\delta}$ finlets. The scales are very small, numbering several humdred along the lateral line. The color is dark blue alove

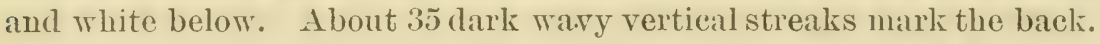

The common macherel closely resembles the other species of the same genus found on both the Atlantic and Pacific coasts, namely, the bull'seye, chub, or thimble-eye mackerel ( $N$. colias), but is separated from it by the absence of the air-bladder, more dorsal spines, smaller eye, and somewhat different markings.

The length of the full-grown mackerel is 17 or 18 inches, but fish a little over 20 inches long, and weighing upward of $3 \frac{1}{4}$ or 4 pounds, are occasionally taken. The average length of the market catch is about 12 inches. Such a fish weighs from three-fourths of a pound to a pound.

Small mackerel are known among the fishermen by several names, such as "spikes," "blinkers," aud "tinkers." Spikes are the smallest cadight by the commercial fishermen; they are 5 or 6 inches long and are 5 to 7 months old. Tinkers are under 9 inches in leugth aud are supposed to be about trro years old. Blinkers are intermediate in size and age. Maturity is probably attained in the fourth year.

DISTRIBUTION, MOVEMENTS, ABUNDANOE, AND SPAWNING.

This species inhabits the North Atlantic Ocean. On the American coast its range is from Cape Hatteras to the Straits of Belle Isle. On the European coast the fish is found from northern Norway, in latitude 
710, to the Mediterranean and Adriatic. It is not recorded from the West Indies, Bermudas, Gulf of Mexico, Soutl America, or Africa.

On the eist coast of North America mackerel first appear in the spring off Cape Hatteras and subsequently reach the shores of the Niddle and Yew Ingland States and the British possessions, migrating in from the sea from a southerly or southeasterly direction. Certain bodies of fish seek the New England shore, while others first strike the shore of Nova Scotia and follow it into the Gulf of St. Lawrence. They leave the coast in the same way in fall and early winter.

The mackerel is a wandering fish. Its movenents when in the coast water's are undombtedly reguated by externai causes not yet clearly understood, but food, temperature of water, and reproduction are potent factors.

The mackerel is one of the most abundant fishes found on the Atlantic coast. It goes in schools, often of immense extent. The testimony of reliable fishernen relative to the size of schools observed often seems incredible; thus one school seen in the South Channel in $1 S t S$ was half' a mile wide and at least 20 miles long. A nother school noticed off 13 lock Island in 1577 mas estimated to contain 1,000,000 barrels. The schools swim at the surface or at varying depths beneath the surface, and present a comparatively broad front.

From the earliest times, there have been periods of scarcity of mackerel altermating with seasons of abundance. As early as 1670 the Colony of Massachusetts enacted laws for the preservation of markerel. Since 1855 there has been the most noteworthy aud prolonged scarcity of the tish of which there is any record. The Ner England catch in 1855 was 330,000 barrels, and in the 8 years ending in 15 s. arelaged 309,000 harrels; in 1856 it fell to 80,000 barrels, and in the succeerling 10 years aggregated only 4S1,000 barrels; was several times below $25,0(10$ barrels, and never exceeded 89,000 barrels. The yield in 1,S9S Was $5,769,000$ pounds, fresh, valued at $\$ 307,000$, and 15,500 barrels, salted, worth $\$ 179,000$.

The spawning season on the east coast of North America includes the months of May, June, and July, June probably being the principal month. The spawning-grounds are in rather deep water and extend along the entire coast from Long Island to the Gulf of St. Lawrence. Most of the bays and sounds of the New England coast are important spantring-grounds, as is also the Gulf of St. Lawrence. Prior to spanning and for sereral weeks thereafter the mackerel are lean and poor and never make No. 1 fish when salted.

\section{FOOD AND ENEMIES.}

The mackerel feerls on a large variety of small animals, and is in turn eaten by a number of fishes, birds, cetaceans, etc. The relations existing between the presence of favorite food and of enemies on one hand and of mackerel on the other are fully appreciated by the commercial fishermen, who are often guided in their search for fish by the appearance of mackerel food in abundance or of their well-known 
enemies. The presence of food is frequently shown by flocks of birds, especially phalaropes, which are called "mackerel geese."

The principal food objects of the mackerel are small crustaceans; copepods predominate, but shrimps of varions kinds, young crabs, etc., are also important. One of the surface-swimming copepods, known as "red feed," "cayenue," etc., is a rery favorite food; when mackerel have been feeding freely on it, they spoil very quickly after being caught, owing to their sides rotting or "burning." Fish constitute a rather important part of the mackerel's diet; herring, anchovy, saud lannce, silversides, menhaden, and many other small fishes are eateu.

Among fishes, sharks are, perhaps, the most destructive enemies; mackerel sharks and dogfish are known to prey on the mackerel, driving and scattering the schools. Other fish enemies are bluefish and col. Porpoises and whales are often seen feeding on the mackerel schools. Large squids do great damage to small mackerel. Among birds, the gannet is especially destructive.

\section{THE IIACKEREL FISHERY.}

The mackerel is one of the best and most valuable food-fishes of the Atlantic Ocean. It is the object of important fisheries in Norway, Ireland, and Great Britain, and is extensively taken in the United States and the British provinces of North America. The fishery is prosecuted with vessels using purse seines, gill nets, and lines, much the largest part of the eateh being taken in seines. In the boat fishery, lines and nets are employed. Stationary appliances, such as pound nets, trap nets, and weirs, also secure considerable quantities of mackerel.

In the United States the vessel fishery is carried on chiefly from Gloncester, Mass. The vessels sail south in early spring, and fall in with the fish when they first appear off the coast of the Southern and Middle States, the eatch being landed fresh in New Tork and Philadelphia. The fleet next seeks the fish on the sontheru shore of Nova Scotia and follows the school north to the Gulf of St. Lamrence. During the summer some of the vessels enter the gulf, but most of them cruise on the New England shore, where most of the fall fishing is also done. Some ot the finest fishing vessels of the United States are engaged in this fishery. In recent years the fleet has numbered only 150 to 225 sail, but formerly nearly 1,000 vessels were at times employed in this branch.

The shore and boat fishing is carried on from New Jersey to Maine. The fish thus caught are as a rule sold in a fresh condition.

The fishery is much less productive than formerly, and during the past ten years has not as a rule been profitable, although each year a few vessels make good catches and yield very satisfactory returns, owing to the high price of fish. The local fishing does not supply the home demand, and large quantities of fresh and salt mackerel are annually imported from Norway, Ireland, and the British provinces. 


\section{ARTIFICIAL PROPAGATION.}

The artificial propagation of mackerel was more extensively prosecuted in 1896 than in any previons year. The long-continued scarcity of mackerel on the Atlantic coast of the United States seemed to warrant some efforts on the part of the Government to increase the supply by artificial means. The limitations of mackerel culture depend on the erratic movements of the fish in a given season or on a given part of the coast and the difficulty of securing healthy eggs in large quantities from fish taken by the commercial fishermen. During the summer of $1896,24,000,000$ mackerel eggs were collecterl. The work was largely experimental and only a small percentage of fry was hatehed, but the outlook is good for a great expansion of mackerel propagation.

The egg of the mackerel is one of the smallest dealt with by the fishculturist, being only $\frac{1}{2}$ inch in diameter. Being provided with a large oil-globule, it floats at the surfice, like the eggs of many other marine fishes. Within 48 hours after fertilization it generally begins to sink, remains in suspension a short while, and then falls to the bottom, where it remains until hatching ensues.

Owing to the inability to retain mackerel in ponds or live-cars pending the ripening of the eggs, as is done with the cod, it is necessary to depend for the egg supply on the nets of the fishermen. The eggs collected at Woods $\Pi$ ole are secured from fish captured in pound nets near Chatham and at other points on the southern MIassachuset ts coast; at Giloncester traps in the vicinity furmish the eggs. As the nets are usually hauled only once or twice a day, the fish have often been caught for many hours, and the tender eggs have undergone considerable loss of vitality; the quality of the eggs seems to have a direct relation to the length of time the fish have been in the nets.

One of the most favorable grounds for collecting mackerel spawn is Casco Bay, on the coast of Maine. Mackerel are taken chietly in drag nets set about 4 o'clock 1). m., and hauled from 9 o'clock p. m. to daylight. Eggs from fish caught in the first hauls of the nets are of much better quality than those taken in the last lifts.

In collecting eggs from pound nets the spawn-takers accompany the fishermen when they visit their nets and overhaul the mackerel as they are taken into the boats. The collection of eggs from the drag-net fishermen requires the spawn-takers to remain on the fishing-grounds from early in the afternoon until the next morning.

There is nothing peculiar in the methods of stripping the fish, mixing the eggs and milt, and transferring the eggs from the field to the hatchery. Althongh both the wet and the dry methods of fertilization have heen practiced, the latter apparently gives better results. The average number of eggs taken from a fish is probably about 40,000 . Three mackerel, stripped at Woods Hole in 1893, yielded 434,500 ripe eggs, an average of 144,833 eggs. As many as 5 16,000 eggs have been taken from a $1 \frac{1}{8}$-pound fish, and the largest fish probably yield fully $1,000,000$ 
eggs. The largest number of eggs taken from one fish in Casco Bay in 1897 was 200,000 .

From the field the fertilized eggs are conveyed to the station in jars, as described in the chapter on cod propagation. For short shipments they may be transported in buckets or cans.

Mackerel eggs may be artificially incubated in a variety of ways. In 1896 three forms of apparatus were employed for comparative purposes. These were (1) the McDonald hatching-jar, with the water supplied through the long central tube and discharged through a cheese-cloth top; (2) the Chester jar, and (3) the automatic tidal-box; the latter gave the best results.

Owing to the very small size of the eggs, from 200,000 to 225,000 may be placed in a Chester jar and 450,000 or wore in a tidal box 20 by 11 inches. The eggs are manipulated in about the same way that cod eggs are, but, owing to the short period of incubation, require very little handling.

For reasons not yet definitely determined, but apparently connected with the condition of the eggs rather than the methods of hatching, mackerel ova are liable to exceedingly large mortality during incubation. While as many as 75 per cent of certain small lots of eggs have produced fry, less than 1 per cent of most of the eggs hatch.

The period of incubation at a mean water-temperature of $5 \mathrm{~S}^{\circ}$ is about 5 days. In tis hours after impregnation the embryo is discernible, and in 68 hours its development is far advanced. The critical period seems to be the end of the third day, when a large part of the eggs die.

The fry are planted within 24 hours of hatching. They are taken to the natural spawning-grounds in regular trausportation cans and liberated below the surface of the water. 




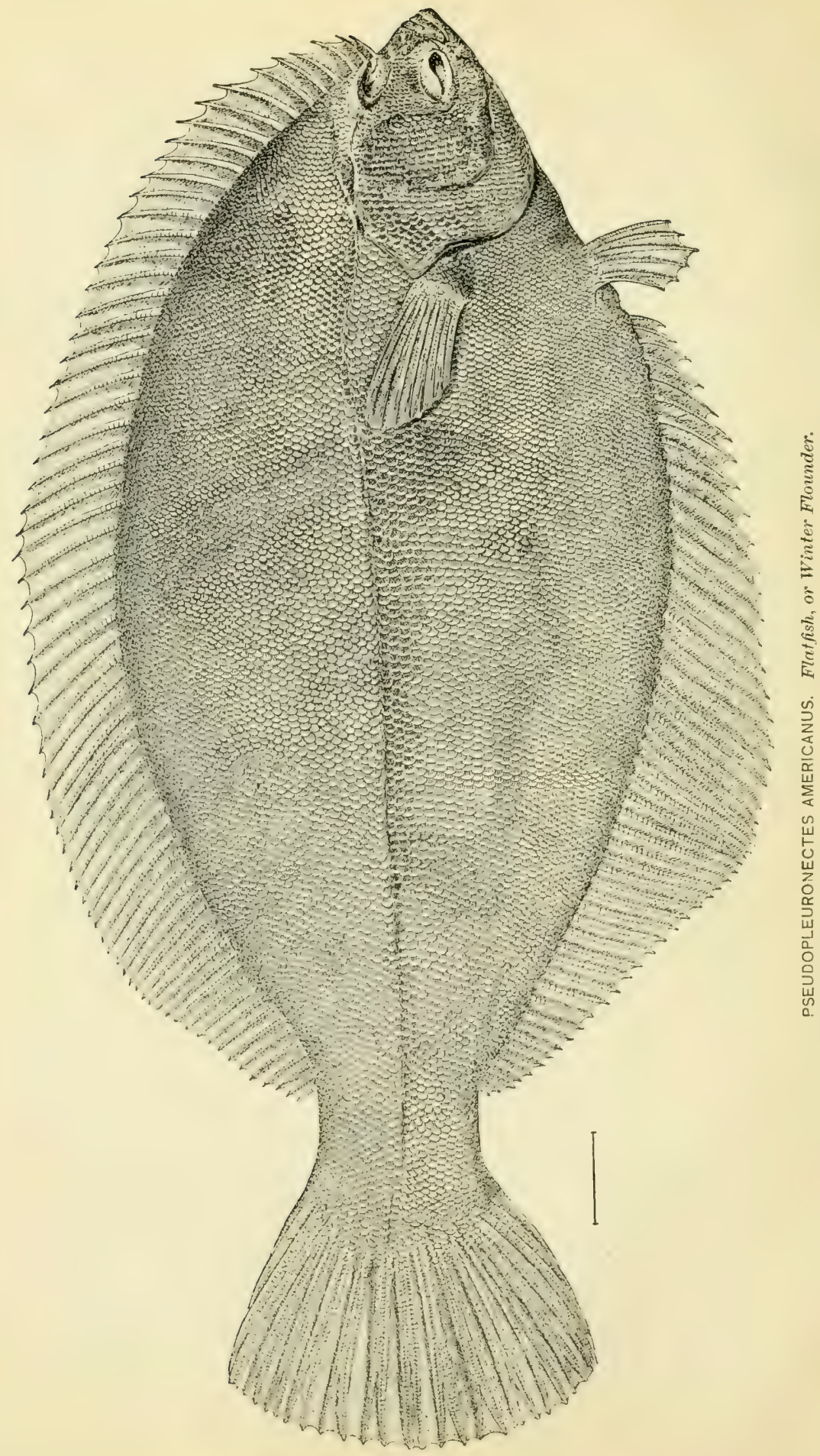




\section{THE FLATFISH, OR WINTER FLOUNDER.}

The body of the flatfish (Prendopleuronectes americanus) is regularly elliptical. The eyes and color are on the right side. The upper side of the head is covered with imbricated ctenoid scales similar to those of the body; the blind side of the head is nearly naked. The teeth are close-set, incisor-like, and form a continuous cutting edge; the right side of each jam is toothless. The length of the head is contained 4 times in the length of the body and the depth 21 times in the body length. The dorsal fin contains 65 rays and the anal fin 48 rays. The lateral line, which is nearly straight, has 83 scales. The color above is dark rusty-brown, either plain or mottled with darker; the young are olivebrown, spotted with reddish; the under parts are white.

This species has a comparatively small mouth, and feeds chiefly on small shells, crabs, and other bottom animals. It is found on sandy, muddy, or rocky bottoms, and seems to prefer sheltered coves and bays. Its coastwise aud bathic movements are limited. It is one of the most abundant flomders of the Atlantic coast, being especially numerous in southern New Eugland and New York. It rauges as far north as Labrador and as far sonth as the Carolinas, but is not present in noterrorthy quantities sonth of New Jersey. It does not attain a large size, the usual length being only 12 to 15 inches and the weight about $1 \frac{1}{2}$ pounds. Very rarely examples are taken over 20 inches long, weighing as much as 5 pounds.

The winter flounder is exceedingly prolific, over a million eggs being laid by a large fish. Along the coast of the sonthern New England and Middle Atlantic States the sparning season is from February to April. By August the young fish, having attained a hength of 1 or 2 inches, are found in shallow water along sandy shores. The species is obtained priucipally during the winter and spring months, and large quantities are sent to the markets, where it sells readily at good prices. The flesh is white, firm, and of excellent flavor. Next to the halibut and the summer flounder, or plaice (Paralichthys dentatus), this is the most important flatfish of the Atlantic coast.

The winter flounder has been more extensively propagated than any other species of Pleuronectide, owing to the facility with which its egers are obtained at Woods Hole, where its propagation fills in the time between the taking of cod eggs on one hand and of lobster eggs on the other, slightly overlapping the ending of the former and the beginning of the latter. The work covers that part of the year when the most 
inclement and changeable weather occurs, and is necessarily somewhat limited in extent by uncontrollable physieal and other conditions.

During the fiscal year 1595-96, the collections of flatfish eggs numbered 11,008,000, which yielded $8,472,000$ fry; in the year 1896-97 S4,591,000 eggss were taken, from which $64,095,000$ fry were hatched.

The flattish from which eggs are obtained are very plentiful during Fehruary in the Woods Hole region, being found on saudy or hard clay bottom. and taken in fyke nets set in water from 6 to 14 feet deep. As many as 60 to 70 tish are sometimes taken at one lift of a fyke net, but as a rule not more than two or three of this number are gravid fish. These nets are usually some distance from the station, and the fish are carried to the hatchery in transportation cans, six or eight being put in one can. In some cases this trip is made by water in a sail or row boat, while at other times it is made overland by team. The fish are often carried 10 or 12 miles without change of water and without apparent injury. A few are caught while the water temperature is as low as $33^{\circ} \mathrm{F}$., but they are more numerous after the temperature reaches $34^{\circ}$ or $35^{\circ} \mathrm{F}$. On arriving at the station the fish are put into wooden tanks supplied with constantly changing water, and here they are held until ripe. It is customary to put both males and females in the same box or tank. The fish are examined daily and the eggs are taken from all which are found to have ripened, the stripped or spent fish being released.

The eggs of the flatfish are quite small, there being 30 in a linear inch. Unlike the eggs of the cod, haddock, mackerel, and other marine fishes, they do not float, but sink to the bottom of the ressel in which they are held. They are not so heavy as those of the lobster, and a slight current causes them to rise and carries them to a point where there is still water, when they again go to the bottom. When first deposited, the eggs are very adhesive and stick together in one mass or in clusters of different sizes. This adhesiveness is overcome, in a measure, by thoroughly washing them, and, as this force gradually weakens as the eggs become older, usually nearly all the eggs are separate when they begin to hatch. The use of dry pow dered starch is very effective for this purpose; this mixes readily with the salt water and admirably overcomes the glutinosity of the eggs. Its action is purely mechanical.

In stripping, it is customary to fill a Chester jar with water and place inside the jar a bag made of cheese-cloth, into which the eggs are allowed to fall. The fish is grasped by the head with the left hand, the month being in the palm of the hand, and the edge on which the vent is located turned from the spawn-taker. The right grasps the fish near the tail, and as it is moved with gentle pressure toward the vent, at the same time that the left thumb is moving crosswise and exerting similar pressure, the eggs are extruded. The milt is then expressed in the same way; the eggs are stirred. slightly with the hand to thoronghly mix them with the milt, and after allowing a short time for the action 
of the milt they are cleaned and the superfluous milt washed off by introducing a gentle stream of water into the bag and rolling the eggs from side to side.

It frequently happens that fish held in tanks to mature deposit their eggs during the night. In such cases the eggs are found on the bottom of the tank the next morning. They are usually in clusters aud when examined with the microscope it will be found that practically every egg is fertilized.

After the eggs have been taken and fertilized the number is calculated by measuring in a glass grarluate and computing 48,726 eggs to the liquil onnce. The average number of eggs is about 500,000 to a fish. On March $6,1897,30$ ounces, or $1,462,000$ eggs, were taken from a fish 20 inches long and 11 inches wide, its weight being 3.5 pounils after the eggs were taken.

Flattish eggs may be hatched in several kinds of apparatus, but the Chester jar is most userl, in combination with the McDonald tidal box employed in incubating cod eggs. From 400,000 to 500,100 eggs are nstually placed in each jar. The top of the jar is covered with cheesecloth held in place by rubber bauds. The jar is then inverted and placed in a tidal box. The usual complement of each box is 2 jars. A wooden frame of 1 -inch strips is placed lengthwise on the bottom of the box for the jars to rest on, so as to raise them and allow the free circulation of the watel. A hole in the bottom of the jar allows the air to pass in and out as the water inside rises and falls. The inner compartment, with a bottom of cheese-cloth, used in cod-hatching is omitted.

As in using the jars the eggs are generally on the bottom all the time, the experiment has been tried of employing the McDonald box with the antomatic current in order to keep the eggs in circulation. It having been found that the current commonly used for cod eggs caused the eggs to pile up in the end nearest the outlet, a stream was introduced into each end of the box and the water was allowed to escape in all directions through a perforated nozzle; the water was kept about 3 inches deep in the bottom of the box by using a quantity sufficient to prevent the breaking of the siphou. By this means a coustant current is formed, the egg's develop nicely, and the fry hatch, but the current necessary to keep the eggs in circulation is strong enough to kill the fry by forcing them against the sides of the box. This experiment is therefore not considered a success.

The period of incubation when the mean water temperature is $37^{\circ}$ or $38^{\circ} \mathrm{F}$. is 17 or 18 days.

The fry of the flatfish, although much smaller than those of the cod, are much more lively, and are straightened out when first hatched. Unlike the young cod, they do not float on the surface, but are seattered through the water from top to bottom, many being seen among the eggs on the bottom of the jars. Unlike the adults, the flatfish fry 
swim with the body upright, as young fish of other families rlo, and when first hatched the eyes are on opposite sides of the hear. At the age of about three months, however, one of the eyes will have moved to the other side of the head, to conform with the change of the body in swimming from an upright to a flat position. The position constantly assumed by the very young fry is peculiar, the long axis of the body being vertical, with the head upward. This is owing to a large oil-globule in the anterior part of the yolk-sac.

The fry are quite hardy and staud transportation very well. They have been liept three weeks withont change of water in a bottle hanging in a box of running water to maintain an even temperature in the bottle. In planting the fry, which is done in one or two days after hatching, they are put into the transportation cans commonly used for such purposes and taken in a boat to localities in which the brood fish are found. The cans are put overboard and sunk until the mouth is submerged, when the contents are gently turned out. For a trip of not more than two or three hours' (luration, with water temperature about $38^{\circ} \mathrm{F}$, from 400,000 to 500,000 fry may be safely carried in a 10-gallon call.

\section{THE SAND-DAB AND FOUR-SPOTTED FLOUNDER.}

Ihesirles the flatfish or winter flounder, two other flounders have been artificially hatched, on a small scale, at Wnods Hole; these are the sand-dib ( Fothus maculatus) and the four-spotted flounder (Paralichthys: ollongus). The eggs of both fish are buoyant, and deposited in May. Those of the former are $\frac{1}{2-4}$ inch in diameter, and of the latter $\frac{1}{2-5}$ inch. The periol of incubation, at a temperature varying from $51^{\circ}$ to $54^{\circ} \mathrm{F}$., is about 8 days. 



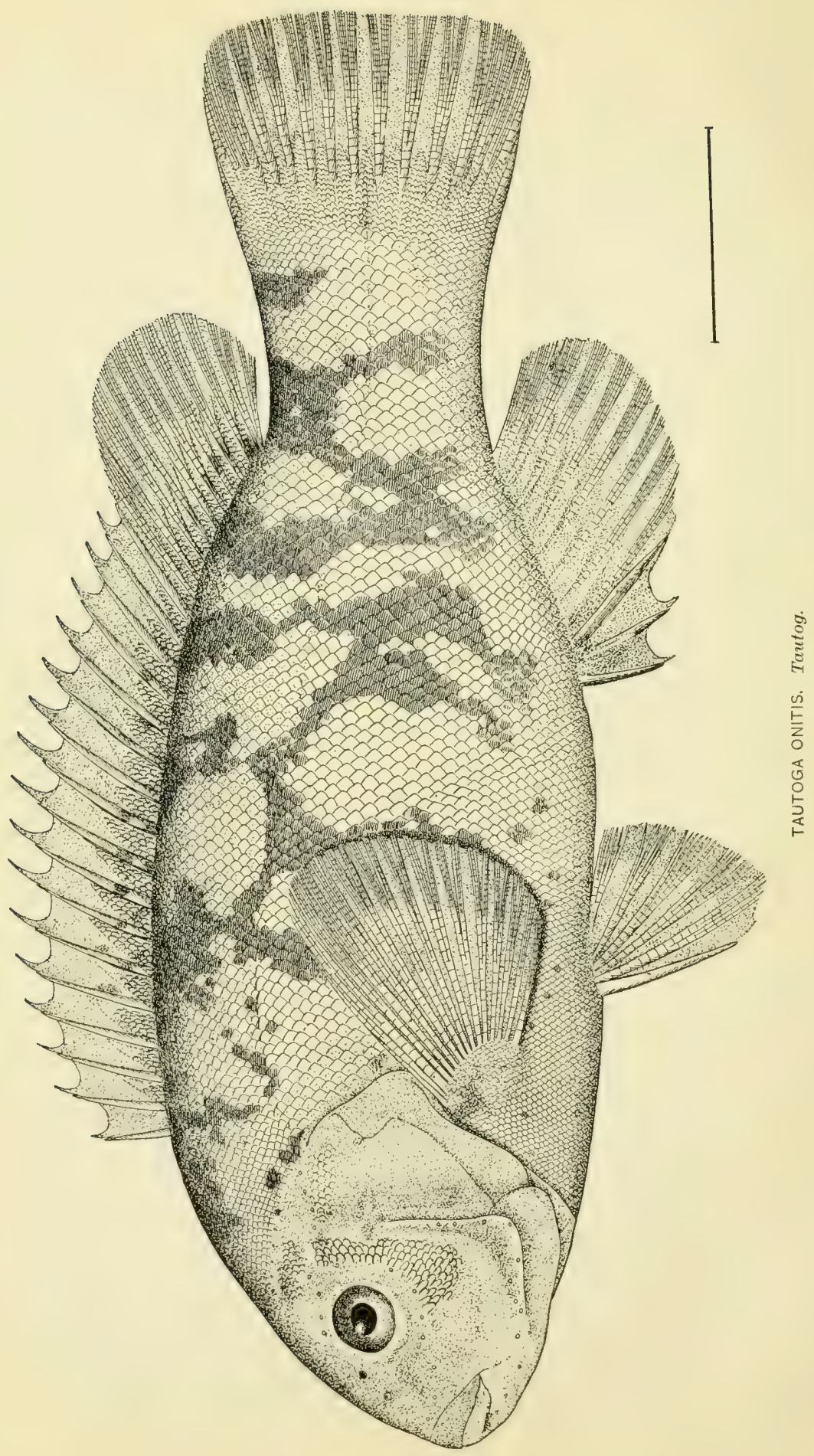




\section{MISCELLANEOUS MARINE FISHES.}

In ardition to the salt-water fishes previously considered, a number of others hare been artificially propagated by the U. S. Fish Commission. With some of these the fish-cultural work has been rather extensive; with others, hardly more than experimental. Among those to which most attention has been given are tautog, Spanish mackerel, pollock, and haddock. Others that have come in for a share of either practical or experimental work are sea herring, seup, sea bass, squeteague, cunner, sheepshead, and several flouṇders.

The same methods of culture mentioned hereafter in comnection with tautog are applicable in greneral to scup, sea bass, squeteague, and other species having floating eggs.

THE TAUTOG.

The tautog (Trutoga onitis) is a strougly marked species. It belongs to a family (Labride, or the wrasses) characterized in part by one dorsal fin, thoracic ventral fins, double nostrils, thick lips, and stroug teeth in the jaws. The tautog has an elongated body and a large head with a convex profile. The rather small month is armed with strong conical teeth in tro series. The eve is small and placed high on the side of the head. The body is covered with small scales, in about 60 transverse rows and to longitudinal series. The head is destitute of scales, with the exception of a small patch behind the eye. The dorsal fin is loug and low, with 16 strong spines and 10 soft rays. The anal fin contains 3 spines and 8 rays. The boly length is 31 or 32 times that of head and $2 \%$ or 3 times the depth. The gillrakers are short, feeble, and number ouly 9. The color of adults is almost uniformly blackish or greenish; the young are marked by dark irregular crossbar's on a pale brownish background; chin, white; iris, bright green.

The tantog is of considerable importance in certain parts of its range. It is found from Maine to South Carolina, but is most abundant in Massachusetts, Ihhode Island, and New Tork. It is one of the bestknown shore fishes of the east coast, and goes by a variety of names, among which are blackfish, chub, oyster-fish, and moll, besides the most generally used name of tautog.

The tautog inhabits principally rocky bottom, where it hides in crevices, often with its body in an apparently very unnatural position. It is quite susceptible to changes in temperature, and during winter enters into a state of hibernation in the more northern parts of its range. Its coastwise movements are very limited. Its sharp strong teeth enable it to consume mollusks and crustaceans, which are its chief food; it also eats sand-dollars, worms, and other animals. 
The tautog is takeu for market in considerable numbers by means of lines and traps. It bites quite readily and is a favorite with anglers. Its average weight as caught for sale is not more than 2 or 3 pounds, but tautog weighing from 6 to 15 pounds are not rare. The maximum weight is about '22 21 pounds; such a specimen from New York, 36. inches long, is preserved in the U.S. National II Iseum. The anmual commer. cial catch of tautog is about $1,000,000$ pounds, valued at $\$ 25,000$. Most of the yield is from Massachusetts, Rhorle Island, and New Jersey.

The spawning season on the southern New England coast extends from April to August, althongh June appears to be the principal montl. The young are very abundant along the shores in the fall.

The artificial propagation of tautog was experimentally unciertaken at Woods $\Pi$ ole in 1S56. In 1896, 31,431,000 eggs were taken in June; from these $17,575,000$ fry wero hatched and planted in neighboring waters.

Tautog from which eggs for hatching are taken are obtained from nets or from line fishermen near the station and transferred to live-cars. When first brought in they seldom yield any eggs, but in "2 to 6 hours they may be stripped of a part of their eggs. The eggs taken after fish are hell more than 6 lours are usually of no value, and those obtained from fish retained one night are invariably worthless.

The tautog is very prolific. In 1 s.96 a 93 -pound fish yielded 1,142,600 egess, and it was estimated that the ovaries contained fully as many more eggs that were not yet mature. The average number of eggs per fish is from 150,000 to 200,000 .

The eggs of the tautog are about $\frac{1}{2}$ inch in diameter. They are buoyant, like those of the mackerel, and are susceptible of the same method of hatcining. When placed in the antomatic tidal bos, they hat $\cdot h$ in about 5 days, with the water temperature at $690 \mathrm{~F}$., and in 2 or 3 days with the temperature at $71^{\circ}$.

The newly hatehed fry are transparent and exceedingly small, the length being only ${ }_{1}^{\frac{1}{2}}$ inch. They are quite hardy and stand transportation well. They are planted shortly after hatching.

\section{THE SPANISH MACKEREL.}

The Spanish mackerel (Scomberomorus maculatus) is the best-known fish of the genus and the only one that has received the attention of fish-culturists. From the other species of Scomberomorus found on the eastern United States coast (S. regulis, the kingfish, and S. caralla, the cero) this fish is, in part, distinguished by its smaller size and by the insertion of the soft dorsal fin in advance of the anal. The body is long, the head small and pointed, the month large and armed with prominent teeth. The anterior dorsal fin has 17 spines, the soft dorsal luas 18 rays. The anal fin has 2 spines and 17 rays. Behind both the dorsal aud anal fins are 9 small finlets. The lateral line is wary and has about 175 pores. The general color is silvery, dark-bluish above aud whitish below. 'The sides have numerous romded yellowish spots. 
This fish is widely distributerl, being found on both coasts of North America. On the rest coast it does not enter United States waters, but on the Atlantic seaboard it ranges from Texas to Massachusetts. It is especially abundant in the Gulf of Mexico, among the Florida keys, in Chesapeake Bay, and on the coast of the Middle Altantic States.

Its maximum weight is about pounds. Many weighing only 1 or $1 \frac{1}{2}$ pounds are caught for market, and the average is less than 3 pounds.

The Spanish mackerel is one of the choicest food-fishes of American waters; in popular estimation it is scarcely surpassed by any marine species except the pompano. It is caught thronghout its range on the east coast with gill nets, seines, pound nets, and lines. The principal fishing is on the west coast of Florida, on the Lonisiana coast, in the lower part of Chesapeake Bay, and on the coasts of New Jersey and New York. The approximate annual value of the catch at present is $\$ 112,000$, which represents $1,700,000$ pounds. In 1880 the output was 1,887,000 pounds, having a value of $\$ 132,000$. The yield in the Jfiddle States is much less than formerly, while in the Gulf States it has increased.

The fish spawns throughout its entire range on the United States coast. The spawning season is quite prolonged, extending from April in the Carolinas to September in New York, and in a given locality continues from six to ten weeks. All of the eggs in the ovaries of a given fish do not mature at one time; eggs in all stages of derelopment may be found, suggesting a comparatively long sparning season for individual fish as well as for the species as a whole. The eggs, when laid, float at the surface, where they are driven abont by wind and tide. Doubtless a large percentage of the eggs do not hatch, through failure of fertilization and by being stranded. The eggs are very small, their diameter being only $\frac{1}{28}$ to $\frac{1}{2}$ of an incly.

The artificial impreguation and hatching of Spanish mackerel eggs were first accomplished in 1850, since which time the propagation of the fish has been taken up on a number of occasions, although the work in any one season has been comparatively limited.

The serious diminution in the supply of this species in certain sections seems to call for its artificial cultivation whenever it can be taken up without detriment to the propagation of other more or equally important fish.

In the work of artificially propagating this fish recourse has been had to the nets of commercial fishermen for the supply of spawn and milt. Chesapeake Bay has been the seat of the principal operations, which have been conducted by the steamer Fish Hawt. The catch of Spanish mackerel in this bay in pound nets and other appliances is very large, and the facilities for fish-cultural work of this character are doubtless superior to those of any other section, with the possible exception of the west coast of Florida.

The necessity for depending on the fishermen for the supply of eggs is somemhat detrimental to the best results and prevents extensive work, although the owners of fishing apparatus heartily cooperate. 
Owing to the fact that the fish appear to spawn mostly at night, when the pound nets are lifted in the morning the ripe eggs have in many "ases been extruded before the spawn-taker conld secure them. The injuries which the fish sustain while in the pound nets and during the hamling of the nets appear to seriously aflect the eggs and cause the non-hatching of a comparatively large percentage. Undoubtedly better results may be obtained if a number of nets are fished exclusively for this purpose, insuring the careful removal of fish at the best times for taking and fertilizing the eggs.

The escis are very delicate and susceptible to meteorologieal influ. ences. Their development is markedly affected by water temperature aud atmospheric conditions; electrical disturbances, as with other fish eggs, are injurious, but to what extent and in what way are not known. The largest number of ripe eggs thus far taken from a single specimen is 60,000 , but the average is only 20,000 .

The Chester jar, such as is used in hatching flatfish eggs, has been fomd the best apparatus for Spanish mackerel eggs. If the jars are kejt clean and not overcrowded, a constant current of water does not seem to lue essential; of a lot of $60,000 \mathrm{eggs}$ in a jar of quiet water, 90 per cent hatched. The cou tidal-box is also adapted to this work.

In ordinary bay water having a density of 1.014 to 1.019 , the eggs are buoyant and remain at the surface until hatching ensues; but in water of low specific gravity they sink and give unsatisfactory results. The period of incubation is very short. Under normal conditions eggs latch in 20 to 30 hours, averaging 25 hours, at a temperature of 750 or $78^{\circ}$. The fry are planted soon after hatching.

\section{HADDOCK, POLLOCK, AND OTHER GADIDAE.}

The methods of culture employed with the cod are applicable to other members of the cod family having buoyant eggs. The I nited states Fish Commission have frequently taken and hatched eggs of the pollock (I'ollachius virens) and the haddock (Melanogrammus reglifinus). Both are important food-fishes, but much less valuable than the cod, and the collection of eggs has gemerally been only supplemental to con work.

The pollock is fom from New Jersey northward. It goes in large schools, which are often found at the surface, thus differing from the cod and haddock. The average reight is 9 or 10 pounds, and the maximm abont 30 pounds. Fishing is chiefly done from small vessels and boats, and is most important in Massachusetts. The value of the aunual catch is about $\$ 65,000$. The pollock is an excellent food-fish in both a fresh and a salted condition.

The eggs of the pollock have at times been gathered in large numbers in the vicinty of Gloucester; during some seasons about $40,000,000$ eggs have been taken. The eggs measure about $\frac{1}{22}$ inch in diameter. The pollock spawning season includes the months of October, November, and December. The fish from which eggs are obtained are taken 
with nets and lines by commercial fishermen; the average number of eggs to a fish is from 200,000 to 250,000 . The period of incubation is somewhat shorter than that of the cod, being 9 days at $4: 3 \circ$ and 6 days at $49^{\circ}$. About 5 days are required for the absorption of the yolk-sac.

The haddock ranges from Delarvare northward, and is, as a rule, very abundant on the "banks" lying off the New England shore. In its habits it is similar to the cod, frequenting the same grounds and being caught at the same time. Its average weight is about 4 pounds and the maximum under 20 pounds. The fishery is very extensive in Massachusetts, most of the catch being landed fresh in Boston. The annual yield is about $50,000,000$ pounds, worth $\$ 850,000$.

The artificial propagation of haddock has been conducted chiefly at Gloncester, where as many as $30,000,000 \mathrm{eggs}$ have been collected in a single season. The eggs are abont ${ }_{1-7}$ inch in diameter, and are quite delicate aud tender. The spawning time extends from Jaumary to June. 'Lhe average production of eggs per fish is about 100,000 .

The eggs are slightly glutinous and have a tendency to form into small lumps during hatching. At a mean temperature of $37^{\circ}$ they hatch in 15 days, and at $41^{\circ}$ in $1: 3$ days. The yolk-sac is absorber in 10 days at a temperature of 410 .

The tomeod or frostfish (Microgarlus tomcoul) has been extensively propagated by the New York Fish Commission. It is a small but excellent food-fish, foumd along the Atlantic coast from New York to the Bay of Fundy. It is most abundant in early rinter, when it approaches the shores and ascends streams for the purpose of spawning. It rarely exceeds 10 or 12 inches in length.

\section{THE CUNNER.}

The eggs of the cunner or chogset (Ctenolabrus arlspersus) are of the same size and character as those of its near relation, the tautog, and are deposited during the same season. In water having a mean temperature of $56 \circ \mathrm{F}$. they have been hatched in 5 clays, in the tidal cor-jar. On account of the small size, great abundance, and comparatively little commercial value, the propagation of the cummer has not been regularly undertaken.

\section{THE SCUP.}

The scup (Stenotomus chrysops) is a rather important small food-fish found along the Atlantic coast from Cape Ann to South Carolina; it is most abundant in southern New England. It spawns in June. The eggs are $\frac{1}{20}$ inch in diameter and hatch in 4 days at a mean tem. perature of $62 \circ \mathrm{F}$.

\section{THE SEA BASS.}

The eggs of the sea bass (Centropristes striatus) are of the same size as scup eggs, are deposited in June, and hatch in 5 days with the water temperature $59^{\circ}$ or $60^{\circ}$. The sea bass is an important food-fish, 
found from Massachusetts to Florida; it is taken in large quantities from New Jersey northward with lines and traps. It attains a weight of 5 pounds, but the average weight is only 1 or $1 \frac{1}{2}$ pounds.

\section{THE SQUETEAGUES.}

The squeteague or weakfish (Cynoscion regalis) is a prominent foodish of the Atlantic and Gulf coasts, the northern limit of its range being in the vicinity of Cape Cod. It goes in immense schools and is taken in large quantities for market, in North Carolina, Chesapeake Bay, Delaware Bay, on the New Jersey and New York coasts, and in southern New England. It varies greatly in size; the average weight is under 5 pounds, but it has been known to attain a weight of 30 pounds. In the vicinity of Woods Hole this fish spawns in June. Its eggs are $\frac{1}{2}$ inch in diameter, and at an average temperature of $60^{\circ} \mathrm{F}$. lateh in 2 days.

The spotted squeteague or "sea trout" (Cynoscion nebulosum) has also been propagater on a small scale. It is a valuable food-fish from Chesapeake Bay southward, being taken in largest quantities in Virginia, North Carolina, Florida, and the Gulf States. Its average weight is 2 pounds and its maximum 10 pounds. It spawns in bays and sounds in spring and summer, the time varying with the latitude. The eggs are buovant, $3:$ inch in diameter, and hatch in about 40 hours at a temperature of $7 \tau^{\circ} \mathrm{F}$. This species has been artificially hatehed on the southwest coast of Florida by the steamer Fish Hack.

\section{THE SHEEPSHEAD.}

The sheepshead (Archosurgus probatocephalus) is generally regarded as one of the best food fishes of American waters. Its deep body, of a grayish color, marked by 8 transverse black bauds, and its peculiarly shaped head, with mouth armed with prominent incisor teeth, make it readily recognized. It ranges from Cape Cod to Texas, but is most abundant from Chesapeake Bay southward. It attains a weight of over 20 pounds, hut the average weight on the Atlantic coast is not over 7 or 8 pounds, and in the Gulf of Mexico scarcely exceeds 3 pounds. In sonthern waters the fish is a permanent resident, but in the northern part of its range it is found only during spring, summer, and autumn. The spawning season is from March to June, according to the locality.

The artificial hatching of the sheepshead has been undertaken on several occasions, but is not regularly prosecuted. The most extensive work was conducted by the Fish Hawk in March and April, 18s!), when $23,400,000$ eggs were taken in the vicinity of San Carlos Bay, on the southwest coast of Florida. These yielded 16,500,000 healthy fry, most of which were planted in local waters.

In capturing spawning fish on the Florida coast it was found that the best time to use the seine was just before sundown, as the flood tide was about to "make." The fish were then easily taken in large numbers. Seine hauls in the morning consisted only of male fish. Spawning 
sheepshead swim in schools, and seem to prefer sandy beaches, along which they resort at a depth of 6 or 8 feet.

The sheepshead egg is very small, transparent, and of less specific gravity than sea water. The diameter is $\frac{1}{3}$ is of an inch, and the number in a fluid ounce is about 50,000 , or $1,600,000$ in a quart.

The eggs are satisfactorily incubated in the ticlal cod-jar, about 300,000 eggs being placed in each jar. The development is very rapid, and in the warm water of the Gulf ( $76 \circ$ or $77^{\circ} \mathrm{F}$.) the eggs hatch in 40 hours. The newly hatehed try are very small, but active and stroug, and withstand considerable rough handling. They are planted when 72 to 80 hours old.

It is probably not practicable to carry on extensive sheepshead hatching worth of Florida, although small quantities of eggs conld doubtless be taken in North Carolina and Virginia.

\section{THE SEA HERRING.}

The sea herring (Clupeu hurengus) may be distinguished from other clupeoid fishes found in United States waters by the following characters: Body elongate and laterally compressed, the depth contained $4 \frac{1}{2}$ times in length; mouth at eud of snout; lower jaw projecting, extending to beneath the middle of eye; roof of mouth with an ovate patch of small teeth; gillrakers long and slender, about 40 below the angle in adults, fewer in young; dorsal fin with 18 rays, inserted slightly behind middle of body; ventral fins beginning beneafh middle of dorsal; anal fin with 17 rays; median line of belly with 28 weak spines or scutes in front of ventral fins and 13 behind fins; scales thin, easily detached, posterior edges rounded, 57 in lateral series; color bluish or bluish-green above, light-silvery below.

The sea herring exists in great abundance on both shores of the Atlantic Ocean north of the latitude of about $37^{\circ}$ north. On the coast of North America it is not regularly abundant south of Cape Cod, but it is occasionally found as far south as Chesapeake Bay. In number of individuals this species is probably exceeded by no other fish. On the Pacific Coast a similar and almost equally abundant species (Clupea pallasii) is found from Alaska to Mexico.

There are no well-defined movements of the herring on the west shore of the Atlantic, if those induced by the spawning instiuct are excepted. There was formerly a distinct shoreward migration, during the winter months, in the Bay of Fundy, but this run has not occurred for a number of years. In many places the herring, especially the smaller individuals, appear to be resident in the shore waters. The maximum length of this fish is about 17 inches, and the uspal length of spawning fish on the United States coast is from 11 to 14 inches.

The herring subsists on minute invertebrates, chief among which are copepods, larval worms, and larval mollusks. In turn it is consumed in enormous quantities by cod, haddock, sharks, and many other fishes. 
With respert to the time of spawning, the herring may be divided into two gronps, one spawning in the spring, in April, May, and June, and the other between July and December. The spring spawning occurs entirely east of Eastport, Maine, aud the fall spawuing principally, but not entirely. west of that place. Probably the greatest spawning grounds south of the Gulf of St. Lawrence are at Graud Lianan, where the egas are deposited principally in July, August, and September. Thence the season becomes progressively later westward, on the coast of Maine occurring between September 1 and October 15; on the eastern coast of Massachusetts, between October 1 and November 1 , and south of Cape Cod from October 15 to December 1.

The female of arerage size deposits between 20,000 and 47,000 egges at a spawning, nsually not far from 30,000. The eggs are deposited upon the bottom, and, being covered with a glutinous material which soon hardens in contact with tlie water, they become firmly attached to extraneous materials, to which they often adhere in masses as large as a walnut. The egg measures about $\frac{1}{21}$ inch in diameter, and is usually polyhedral from mutual pressure exerted by the eggs in masses.

The commercial value of the sea herring is almost incalculable. It is undoubtedly the most important of food-fishes, although in the United States it is surpassed in economic ralue by many marine and freshwater speries. Some time ago the annual yield of the world was estimated at $3,000,000,000 \mathrm{fish}$, weighing $1,500,000,000$ poumls, the principal part of which was taken in Norway. In the New England States the annual catch is abont $70,000,000$ pounds, with a first value of $\$ 600,000$.

The herring has been artificially propagated both in this country and in Europe, but owing to its great abundance the work has been only experimental. In the United States there has as yet been no permaneut diminution of the supply that renders the cultivation of the species necessary, notwithstanding an extremely large fishery and the sacrifice of enormous quantities of very small fish. The first successful attempt to propagate this fish was in 1878 , in Germany, when elaborate experiments were made. In the same year the artificial hatching of the species was accomplished by the U.S. Fish Commission. The eggs, owing to their cohesion into masses, showed a tendency to molding, but this difficulty could doubtless be obviated by the use of starch, as with other cohesive eggs.

Development takes place in water ranging in temperature between $33 \circ$ and 5. ${ }^{\circ} \mathrm{F}$., the time of incubation varying from about forty days at the former temperature to eleven or twelve days at the latter. Sudden and extreme variation between the temperature limits mentioned had little or no effect except to retard or accelerate the hatching in accordance with the rule just mentioned. When water of a temperature lower than $33^{\circ} \mathrm{F}$. was userl many of the embryos were deformed. The degree of salinity of the water does not appear to exert much influence upou the hatching of the eggs. 


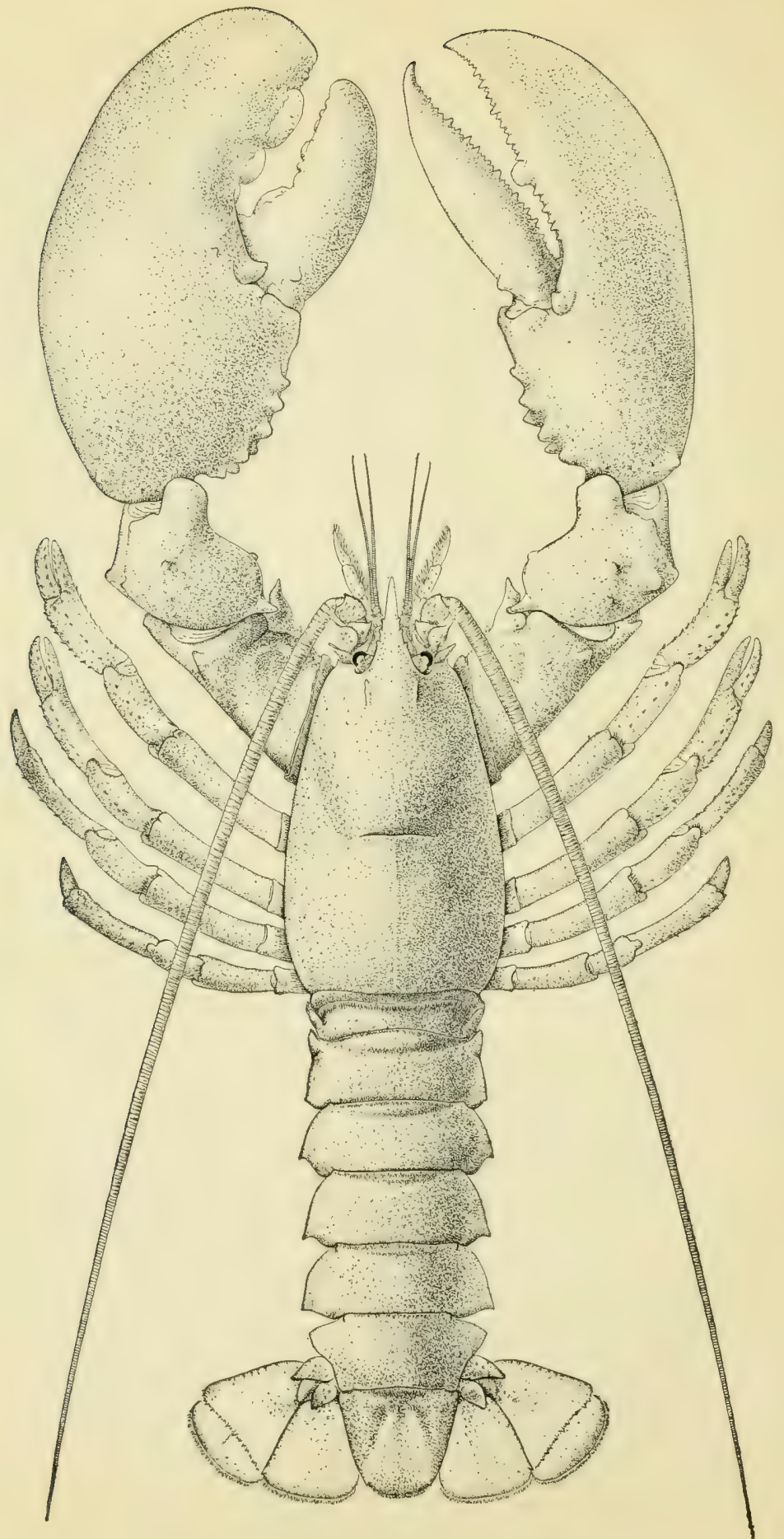

HOMARUS AMERICANUS. Ameriran Lobster. 


\section{THE AMERICAN LOBSTER.}

DESCRIPTION.

The lobster (Homarus americumus) belongs to that group of the crustacea called the Iecaporla, because all of its members are provided with ten feet, more or less adapted for walkiug. 'To the Decapoda also belong the crabs and the shrimps, prawns, aud craytish. The crabs are less related to the lobster than the other forms mentioned, aud may be rearlily distinguished from them by the relatively great brealth of the body and the small size of the abdomen or tail, which is doubled under the thorax to form the "apron." The lobsters, crayfish, shrimps, etc., are elongate forms with the tail or abdomen very large and extended more or less in the same horizontal plane with the anterior part of the body. The lobster and the cray fishes aresomew hat closely related, but differ, among other characters, in the number and structure of the gills and in the relative size of the flat julate or scale which is attached at the base of the antenue or long feelers. The Pacitic Coast crayfishes have 18 gills, those east of the Rocky Mountains have 17, while the lobster has 20. The appendage of the antenna is large in the crayfishes, but very small in the lobster. Moreover, the crayfishes rarely exceed 5 or 6 inches in length, while the adult lobster is much larger, as seen in the marliets, seldom measuring less than 9 $\mathrm{or}^{\circ} 10$ inches. The spiny lobster, the "lobster" of the Pacific Coast, is realily distinguished from the crayfish and the common lobster by the total absence of great claws, by the greater length and stontuess of the antennx, and by the presence of large, loroad-based, spinous proresses on the back.

The body of the lobster is divided into two distinct regions, the cephalothoras and abdomen. The former consists of the head and thonax fused into one united whole. That portion which would constitute the head, were it separate, bears the eyes, the two pairs of feelers, and the month, with the several pairs of moditied limbs which surround that organ and assist in tearing up the food and passing it into the mouth. The thoracic portion of the cephalothorax is furnished with five pairs of stout limbs, the first pair bearing the great claws, which are rarely of the same size on the two sides, and the last four pairs being used in walking. From the fact that this portion of the body bear's five pairs of appendages, it is assumed that it represents five fused segments.

The abdomen is narrower than the cephalothorax and is composed of six separate segments movable on one another. In the female the 
first five pairs of abdominal appendages, known as swimmerets, are all similar and comsist of a short basal piece and two terminal pieces side by side. The appendages of the sixth segment consist of the same arrangement of parts, but the pieces are broad and paddle-like, and, with the terminal plate attached to the last segment, constitute a powerful caudal paddle or tail. In the male the abdomen is narrower than in the female, and the first two pairs of swimmerets differ much from those which follow.

The color of the lobster is subject to great variation, but most frequently is dark bluish-green above, mottled with dark-green blotohes; there is usually more or less red or vermilion on the appendages, especially on the tubercles, tips, and under side of the great claws and on the antenna'; the walking legs are light blue with redclish tips and tufts of hair. Occasionally specimens are found which are almost entirely red, and more fiequently they are hlue or bluish in general tone.

\section{DISTRIBUTION AND ABUNDANCE.}

The lobster is found from Labraclor to Delaware, its range covering about 1,300 mules of coast line. Stragglers have been taken on the coasts of 'Virginia and North Carolina. While the bathic range is pracfically limited by the 100-fathom line, it is oceasionally foumd long distances from land on the tishing-banks off the New England coast.

The lobster is most abundant in the northern part of its habitat. On the United States coast it is most numerous in Maine. In the provinces of Nova Scotia, New Brumsick, and Quebec, and also in Newfoundland it is extremely abundant.

\section{MOVEMIENTS.}

The movements of the lobster are chiefly on and off' shore. Such coastwise movements as characterize the mackerel, bluefish, and menhaden are nerer undertaken by the lobster. 'This fact makes possible the rapid depletion of fishing-grounds, and even the practical extermination of the lobster in given areas; it also aflords basis for the belief in the efticacy of artificial means for maintaining and increasing the supply.

There are well-marked movements of the lobster induced by various influences, among which are the abundance or scarcity of food, the water temperature, and the spawning instinct. On the United States coast there is in the spring months a shoreward movement of large bodies of lobsters; on the approach of winter the lobsters move out. into deep water.

\section{FOOD.}

The principal food of the lobster is fisin, either dead or alive. Such bottom species as the sculpin, flomder, and sea-robin can dombtless be readily canght by the lobster, and they also consume a large number of invertebrates, among them being crabs and other crustaceans, clams, conchs, and other mollusks, starfish, sea-urchins, etc. Lobster eggs 
have been found in a lobster's stomach, and algit sometimes serve an food. Fish is the bait most extensively employed in the lobster fishery.

\section{REPRODUCTION.}

The reproductive function of the lobster is not generally unclerstood, and until a comparatively recent date a number of important questions in relation thereto were undecided. From the standpoints of the commercial fishemen, fish-culturist, and legislator. it is necessary that the principal phases of this subject be clearly appreciated, in order that the supply may be maintained.

The principal spawning season for lobsters on the Cnited States coast is summer, especially July and August, when probably three-fourths of the lobsters deposit their eggs. The remaining egg-producing lobsters lay during the fall and winter. A given lobster does not spawn oftener than every second year, as has been shown by recent studies conducted by the Commission.

The eggs are fertilized outside the body of the female. The spermatic fluid is deposited in a receptacle at the base of the third pair of walking legs, and retains its vitality for a long time. When the eggs: are being extruded, the female lobster lies on her back and folds the tail so as to form a kind of chamber to retain the eggs. A fiter their discharge from the body, the eggs become coated with a cement substance secreted by glands in the swimmerets; this substance hardens after being in contact with the water and firmly unites the egg's to the hairlike filaments on the swimmerets. The exact method by which the fertilizing principle is conveyed to the eggs from the pouch in which it is contained is not known.

The incubative period is much prolonged. After the eggs are extruded and become attached exterually, they are carried 10 or 11 months before hatching ensues; during this time they are carefully protected, and are perfectly aerated by the active motion of the swimmerets. On the United States coast most of the lobsters emerge from the egg in June, although some of the hatehing is completed in May and some in July or even later. A few eggs are now known to hatch in winter. All of the embryos do not come from the eggs at the same time, the hatching occupying a reek or more. The roung receive no attention from the adults, but lead an independent existence immediately after escaping from the egg.

The lobster egg is about $\frac{1}{15}$ inch in diameter. When nemly laid it is usually of a dark-green color, but is sometimes light-grayish or yellowish-green.

The known maximum number of eggs produced at one time by a lobster is 97,440 ; the average from lobsters taken for market is 10,000 to 12,000 . The number depends largely on the size of the lobster, apparently in conformity to the following rule: The numbers of eggs laid by given lobsters vary in a geometric scale, while the lengths of the lobsters vary in an arithmetic scale. 
The following table illustrates, with approximate accuracy, the egoproducing capacities of lobsters of the lengths indicated under normal conditions:

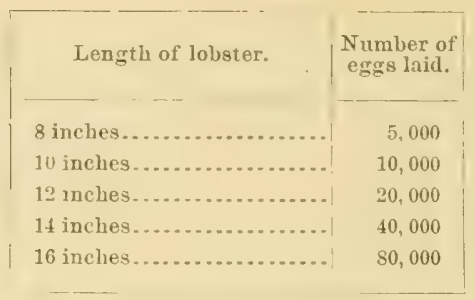

\section{MOLTING AND GROTVIH.}

The act of shedding the shell, or molting, is important and critical. It is only after shedrling that growth takes place; during the early stages of the lobster's existence this function is often exercised in a "omparatively short time, while later it occurs only at long intervals. Molting in the lobster cousists in throwing off the entire external sheleton, together with the lining of the digestive tract.

The first molt takes place abont the time the young emerges from the egg, when it is about a third of an inch loug, and many lobsters do not survive this. Duriug this first stage the laval lobster swims at or near the surface. A second molt emsnes in from 1 to 5 days, and the lobster enter's on its second stage, its average length being about two-fifths of an inch and its habits similar to the first stage. In 2 to 5 days another molt takes place, and the length of the larva increases to about half an inch. This is followed in "2 to 8 days hy another molt, and the lobster enters on the fourth stage, wheu its length becomes slightly greater. From 10 to 20 days later the fifth molt ushers in the fifth stage, atter which the surface-swimming habit is discarded and the larva goes to the hottom and hegins to assume the characteristics of the adult. This stage lasts 11 to 18 days, and in it the young lobster has attained a lengtl of about three-fifths of an inch. From this time on the molts are at longer and longer intervals until the fully mature condition is realuerl, when sherling takes place only once in one or two years.

The fool of lohsters cluring the larval stages consists chiefly of small erustaceans. A very pugnacious instinct then characterizes them, and active ('annibalism prevents their artificial rearing for lack of abuudant natural food.

Larval lobsters are very susceptible to the influence of the sun (heliotropic) while in the first three stages, being attracted by bright rays to the surface of the ocean or to the side of a ressel. This peculiarity is lost during the fourth stage.

Inring the first year the young lobster, which since the fourth stage has berome more and more like the alult in form and habits with each molt, attains a length of about 2 or 3 inches. At the end of the second 
year the length is 5 to 7 inches. By the end of $4 \frac{1}{2}$ or 5 years a length of about 10 inches is reached. The rate of growth, howerer, depends greatly on the environment, the abundance of food being a very important factor.

The adult lobster usually molts in summer, and in the case of the female, shortly after the hatching of the eggs. As several months are required for the new shell to acquire the harduess of the old; as newlylaid eggs are rarely found on a soft-shell lobster; as molting does not ensue while the eggs are on the swimmerets; and, furthermore, as dissection has shown that the ovaries of a lolster whose eggs have recently hatched are in an immature condition and will not yield eggs until the succeerling year, it follows that the mature lobster deposits eggs not oftener than once in two years. with an alternating molt.

\section{SIZE AND WEIGHT.}

The average size of lobsters caught for market is now much less than it was in the earlier days of the fishery, and their average weight is probably not over 2 pounds. A lobster 9 inches long weighs, on an average, $1 \frac{1}{6}$ pounds; a $10 \frac{1}{2}$-inch lobster, $1 \frac{3}{4}$ pounds; a 12 -inch lobster, 3 pounds; and a 15.inch lobster, 4 to 5 pounds; while a lobster 20 inches long weighs 20 pounds or more. Lobsters weighing as much as 15 or 20 pounds are uncommon, and those weighing over 20 pounds are very rare. Up to a recent date, the largest lobster of authenticated weight wa: about 25 pounds. In 1897, howerer, 3 lobsters, each weighing orer 30 pounds, were taken oft' Sandy Hook. X.. J.. the weight of the largest being 33 pounds.

The male lobster weighs more than the female of the same length, the difference in 11-inch lobsters, for instance, being about a quarter of a pound.

The size at which the lobster attains sexual maturity is a very important question. In the New England and Middle States and the Canadian Provinces the laws relating to the minimum size of marketable lobsters are quite varions aud illustrate the absence of definite information on this subject. In Haine, Massachusetts, New IIampshire, and New York the minimum limit of size of lobsters that may be sold is now 10.1 inches: in Rhode Island it is 10 inches, and in Connecticut it is 9 inches. In the British Provinces the limit is much lower than in Maine.

Investigations conducted by the Fish Commission on the New England coast show that the female lobster attains maturity when from 8 to 12 inches loug. Comparatively fer lobsters under a inches in length lay eggs. Of over 1,000 egg-bearing lobster's collected at Woods Hole during a period of years, less than 2 per cent were under 9 inches long. On the other hand, by the time they have reached the length of $10 . \frac{1}{2}$ inches most lobsters will have produced eg'gs, and this should be the minimum size permitted in the markets. 
COMMERCIAL VALUE.

The lobster is the most important crustacenn of the United States. It is the object of a special fishery, carried on with pots or traps, in all the coastal States from Delaware northward. and also in Nova Scotia, New Brumswick, Prince Edward Island, Qnebec, and Newfoundland. In Maine, where the fishery is more important than in auy other State, the lobster is the principal fishery product. Over 4,500 persous are engaged in this fishery in the United States; the capital invested is about $\$ \$ 75,000$, and the cateh in 1896 anomuted to $15,1: 1,000$ pounds, valued at $\$ 1,319,000$. In 1850 the yield was lareer (20,240,000 pounds), but the market value was much less, being only $\$+\$ 8,000$.

Between 1sis and 1.89! the New England lobster "atch decreased over $1.5,000,000$ pounds, or jo per cent, while the value increased more than $\$ 400,000$, or 50 per cent. For a number of years this dishery presented the anomaly of a diminishing supply and an angmented catch, owing to the more active prosecution of the business; but the declime in the yicld has for some time been unchecked, notwithstanding the employment of more apparatus and the prolougation of the fishing season. With a singular disregard for their own weltare, many fishermen have continually violated the State laws for the protection of small, immature lobsters and females bearing eggs. Only the rigid enforcement of restrictive measues by the States and the extensive artificial propagation of the lobster can wark oft the destruction which threatens this valuable fishery.

\section{INCEPTION AND PROGRESS OF LOBSTER-CULTURE.}

If egg-bearing lobsters were not liable to destruction by man, artificial propagation would hardly be necessary. Notwithstanding the enactment of stringent laws prohibiting the sale of "berried "lobster's, the frequent sacrifice of such lobsters, with their eggs, and of many immature lobsters, has seriously reduced the lobster output and rendered active and stringent measures imperative. By the present methods millions of lobster eggs are annually taken and hatched that would be lost, and the females producing them, amounting to several thousands, are liberated.

Prior to 1885 experiments had been conducted at various points looking to the artificial propagation of the lobster. The only practical attempts of this nature previous to those made by the Fish Commissiou were by means of "parking," that is, holding in large naturally inclosed basins lobsters that had been injured, soft-shelled ones, and those below marketable size. Occasionally female lobsters with spawn were placed in the same inclosures. (One of these parks was established in Massarhusetts in 1si:. but was afterward abandoned; another was established on the coast of Maine about 1575 . It was soon demonstrated, however, that the results from inclosures of this character, so far as the rearing of the lobsters from the young were concerned, would not be sufticient to materially affect the general supply. 


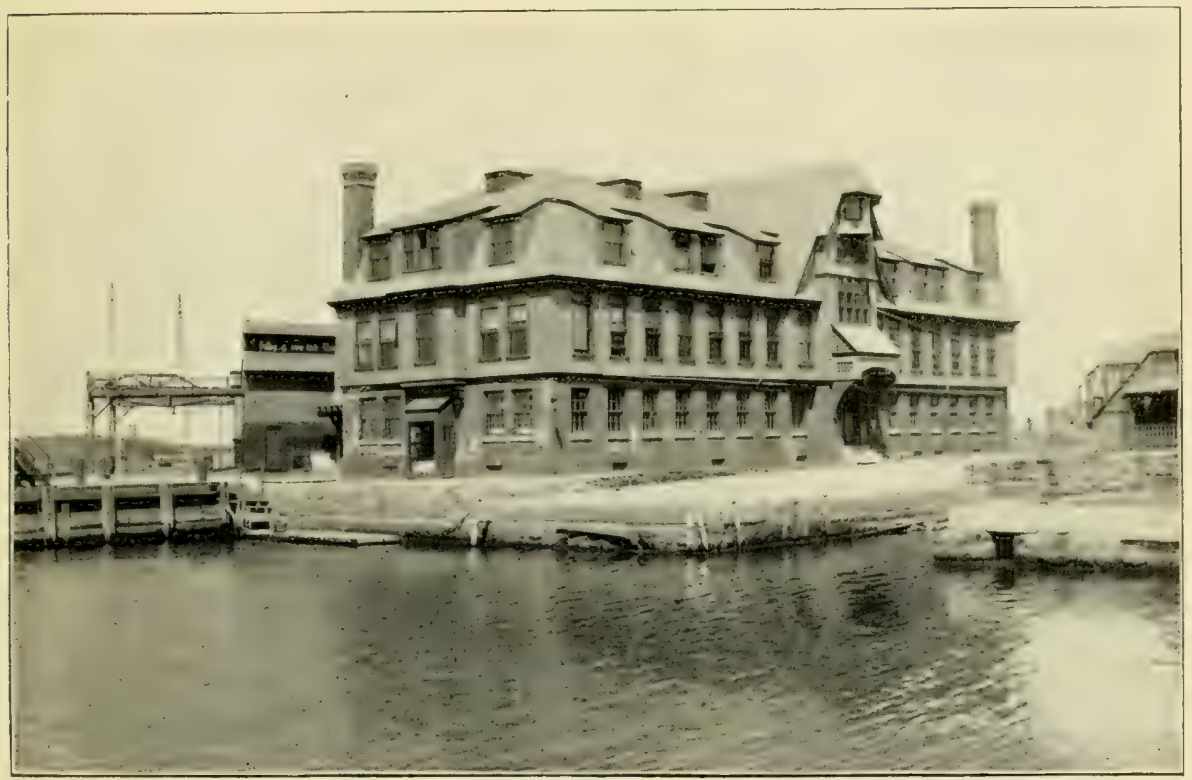

LABORATORY, HATCHERY, AQUARIUM, AND MUSEUM, U. S. FISH COMMISSION, WOODS HOLE, MASS,

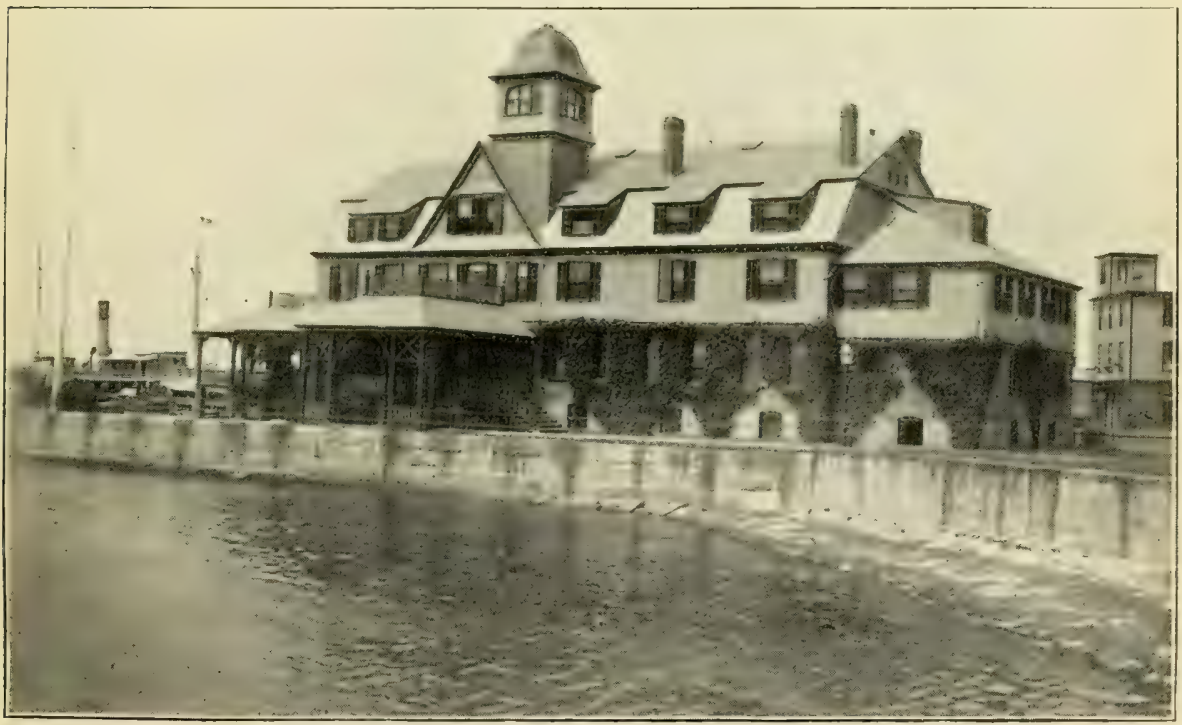

RESIDENCE, U. S. FISH COMMISSION, WOODS HOLE, MASS. 

The completion of the new marine laboratory and hatchery at Woods Hole in 1S55, with its complete system of salt-water circulation, permitted the commencement of experiments in artificial hatching on a large seale, which har not been practicable theretofore, although small fuantities of lobster eggs, as well as those of other crustaceaus, had been sucessfully hatched. In 1886 the experiments harl progressed so successfully that several million eggs were collected and hatehed at Woods Hole, the fry being deposited in Vineyard Sound and arljacent waters. From 1887 to 1890 , inclusive, the number of eggs collected was $17,821,000$.

From the eggs collected up to $18 x+$ the average production of fry was about $\tilde{y}+$ per rent. Inring these years experiments rere conducted as to the best method of hatching the egos. The various forms of apparatus nsed were the Chester jar, the IIolonald tidal box, and the MeDonald antomatic hatching-jar. In 1ss!) the results secured in the latter form of apparatus were so much vetter than with the others that It was adopterl, and in 1890 , from the 4,;5:3,000 eggs collected, over $\$ 1$ per cent yielred fiy. Work was continued at Woorls Hole on about the same scale until 1594, when the collections agrregated $97,000,000$ esgs. In the same year lobster propagation was undertaken at (i.loncester and a collection of $10,000,000$ eggs was made there.

During the fiscal rear 189 ; the number of eggs taken by the Fish Commission was 105,1S5,000, the resulting fir libuated uumbering 97,57!9,000, or about 9.3 per cent; and in 1.897 the collections amounted to $13: 3,562,000$ eggs, of which $115,606,000$, or 90 jer cent, were hatched.

\section{COLLECTION OF EGG-BEARING LOBSTERS.}

Although the new eggs appear on the lobsters during the mouths of July and August, no special effort is made to secure egg-bearing lobsters until the following spring. The collections usually commence in April and continue until the middle of July. At Wools Hole it has been the recent practice to receive at the station and place in the hatching-jars during the fall and winter any lobsters having external eggs that may be captured by local fishermeu. The collecting-grounds extend from Yew London, Connecticut, to the eastern end of Maine. For Woods Hole station eggs are secured from fishermen operating between New London, Connecticut, and Plymouth, Massachusetts.

The most important grounds in Connecticut are in the vicinity of Xew London and Toank; in Massachusetts, New Bedford, South Dartmouth, Plymouth, Woods Hole, and numerous localities in Buzzards Bay aud Vineyard Sound. Eggs for the Gloncester station are secured from the fishermen operating between Boston and Rockland, which territory comprises the most important lobster fishery in the United States. The schooner Grompus is used in making the collections between Portland and Rockland, the lobsters being delivered at Gloncester early in the season and later on to the steamer Fish Huwk, which is stationed at a suitable point in Casco Bay. 
As the laws of Massachusetts, New Hampshire, and Maine prohibit the holding of the "berried" lusters by the fishermen, arrangements are matle with the State authorities ly which certain officials of the Fish Commission are appointed deputy wardens and authorized to holil eggbearing lobsters for fisll-cultural purposes in live-boxes. Early in the spring all of the lobster fishermen in the territory referred to above are visited by agents of the Commission, who arrange with them to hold all of their egg lobsters in live-car's until called for, at a price agreed on.

Collections are made from Woods Hole and Gloucester by steam lannches and sailing ressels. The steam launches visit the near points three to four times a week to obtain egg-bearing lobsters. The ressels collect at more distant points in Connecticut and Maine. Local agents at Boston and Plymouth. Massachusetts, and Kittery Point, Maine, also collect egg-bearing lobster's, which are held in live-boxes until the agent has a sufficient number to make a trip. (On the arrival of the vessel or launch at the station the lobster's are transterred to tanks supplied with running water and held until the spawn-taker is ready to strip the eggs.

\section{TAKING AND MEASURING THE EGGS.}

The receptacle 1 to which the spawn-taker strips the eggs from a lobster is cither' a glass far (9 inches in diameter) or a water-bucket, which, after thorongh cleaning, is partly filled with water.

The operator, with his left land, grasps the lobster from above and turns it on its back, lowering it into the spawning ressel head downwark. By pressing it firmly against the sides of the jar it is prevented from using the anterior part of its borly or its mandibles. The hand is then slipped farther back toward the tail and the segmented portion of the body is helil firmly to prevent its closing. The lobster is then ready for stripping. A rather dull, short-bladed knife is used to separate the exgs from the swimmerets, to which they are attached by hair-like fiber's; stripping begins at the last pair of swimmerets and gradually proceeds toward the hody. As the egges are scraped oft they fall into the water in the jall. Some which athere to the rlatss of the lobster are washerl off by means of a small stream of water. The lobster is then put back into a tank, where it remains until liberated.

Lobsters received by the Ional agents at IBoston and Kittery P'oint are beld until a suitable quantity is on hand and are then stripped, the egess heing taken to the station in transportation cans and the aduits releaserl. Early in the spring the eggs stand transportation well, but late in the season, as incubition becomes more and vanced, they are very delicate and are quickly affeeted by rough handling or sudden changes in temperature.

liefore being transferred to the hatehing-vessels the eggs are acenrately measured, generally with a glass graduate, into which they are ponred, the water being drawn off. The basis of measure is an ounce, which contains about 6,090 eggs. 


\section{HATCHING APPARATUS AND OPERATIONS.}

Experiments conducted during a series of years having demonstrated that the automatic hatching-jar was the best form of alluaratus for hatching lobster eggs, it has beeu adopted at the stations of the Commission since 1889. A full description of this jar is given in the article on shad-eulture, p). 150-15:. The manipulation and operation of the jar is practically the same as with shad eggs, except that frequently, where the water supply is inadequate, three jars are connected by means of rubber tubing and the water used over and over. This is accomplished by connecting the overflow from the first jar with the supply to the second and so on, but can only be done during the early stages before the fry commence to hatch. When first placed in the jar the eggs are matted together by the fine hair-like fiber's, but after a fer days they separate and work very much like shad eggs.

From 400,000 to 500,000 eggs (equivalent to about 2 to $2 \frac{1}{2}$ quarts) are usually placen in each jar, although at times when the hatchery is crowded a few more may be successfully cared for.

The fry pass voluntarily from these jars to cylindrical glass jars, 9 inches in diameter and either 9 or 18 inches high, placed in the center of the table and covered with cheese-cloth at the top to prevent their escape.

The period of incubation depends entirely upon the age of the egg when collected. For example, eggs taken in October do not hatch nntil the following May, whereas eggs collected in June frequently hatch in 24 hours after being placed in the jars. During one season eggs collected from December 12 to January 25 , numbering $1,717,000$, at a temperature of $45^{\circ}$, commenced hatching May 25 at a temperature of 540. To determine how soon the new-laid eggs can be taken from the parent and hatched artificially, collections were begun early in July and coutinned until fall, for several seasons, the eggs being placed in hatching-jar's at the Wools Hole Station; all those collected prior to October 15 died. In November, 1895, 15,000,000 were placed in jars and carried through the winter under very unfarorable conditions, but Latehed with a loss of only 50 per cent. The density of the water at Woods Hole varies from 1.0.3 to 1.025 , its avernge temperature being from $49^{\circ}$ to $64^{\circ}$ during the months of April, May, and June.

\section{THE LOBSTER FRY.}

Owing to the cannibalistic habits of young lobsters when closely crowded, it has been the policy of the Commission to liberate the fry as soon after hatching as possible. They are taken out in ordinary 10-gallon trausportation cans, about 200,000 being placed in a can for short shipments and 125,000 for long shipments, and liberated in the vicinity of the grounds from which the adult lobsters were taken. When this is impracticable, they are liberated in Vineyard Sound and Buzzards Bay with an outgoing tide, so as to insure their wide distri- 
238 REPORT OF COMMISSIONER OF IISH AND FISHERIES.

bution. The question of the transportation of lobster fry any great distance is still an unsettled one, as in but few instances has it been attempted to ship them by rail, and then the trips were comparatively short-namely, from Woods IIole to Cold Spring Harbor, New York; from Woods Hole to Provincetown and I'lymouth, and from Gloucester to Kittery Point. The shipments from Woods Hole have all been very successful, and there seems little doubt that the young lobster will stand transportation for 24 hours with excellent results. 


\section{.}







-

.

- 
